\title{
Particulate-phase mercury emissions from biomass burning and impact on resulting deposition: a modelling assessment
}

\author{
Francesco De Simone ${ }^{1}$, Paulo Artaxo ${ }^{2}$, Mariantonia Bencardino ${ }^{1}$, Sergio Cinnirella ${ }^{1}$, Francesco Carbone ${ }^{1}$, \\ Francesco D'Amore ${ }^{1}$, Aurélien Dommergue ${ }^{3}$, Xin Bin Feng ${ }^{4}$, Christian N. Gencarelli ${ }^{1}$, Ian M. Hedgecock ${ }^{1}$, \\ Matthew S. Landis ${ }^{5}$, Francesca Sprovieri ${ }^{1}$, Noriuki Suzuki ${ }^{6}$, Ingvar Wängberg ${ }^{7}$, and Nicola Pirrone ${ }^{8}$ \\ ${ }^{1}$ CNR-Institute of Atmospheric Pollution Research, Division of Rende, UNICAL-Polifunzionale, 87036 Rende, Italy \\ ${ }^{2}$ University of Sao Paulo, Sao Paulo, Brazil \\ ${ }^{3}$ Univ. Grenoble Alpes, CNRS, IRD, IGE, Grenoble, France \\ ${ }^{4}$ Institute of Geochemistry, State Key Laboratory of Environmental Geochemistry, Chinese Academy of Sciences, \\ Guiyang, China \\ ${ }^{5}$ Office of Research and Development, US Environmental Protection Agency, Research Triangle Park, NC, USA \\ ${ }^{6}$ National Institute for Environmental Studies (NIES), Ministry of Environment, Okinawa, Japan \\ ${ }^{7}$ IVL, Swedish Environmental Research Inst. Ltd., Göteborg, Sweden \\ ${ }^{8}$ CNR-Institute of Atmospheric Pollution Research, Area della Ricerca di Roma 1, Via Salaria km 29 300, Monterotondo, \\ 00015 Rome, Italy
}

Correspondence to: Francesco De Simone (f.desimone@iia.cnr.it)

Received: 29 July 2016 - Discussion started: 1 August 2016

Revised: 9 January 2017 - Accepted: 12 January 2017 - Published: 8 February 2017

\begin{abstract}
Mercury (Hg) emissions from biomass burning (BB) are an important source of atmospheric $\mathrm{Hg}$ and a major factor driving the interannual variation of $\mathrm{Hg}$ concentrations in the troposphere. The greatest fraction of $\mathrm{Hg}$ from $\mathrm{BB}$ is released in the form of elemental $\mathrm{Hg}\left(\mathrm{Hg}_{(\mathrm{g})}^{0}\right)$. However, little is known about the fraction of $\mathrm{Hg}$ bound to particulate matter $\left(\mathrm{Hg}^{\mathrm{P}}\right)$ released from $\mathrm{BB}$, and the factors controlling this fraction are also uncertain. In light of the aims of the Minamata Convention to reduce intentional $\mathrm{Hg}$ use and emissions from anthropogenic activities, the relative importance of $\mathrm{Hg}$ emissions from $\mathrm{BB}$ will have an increasing impact on $\mathrm{Hg}$ deposition fluxes. $\mathrm{Hg}$ speciation is one of the most important factors determining the redistribution of $\mathrm{Hg}$ in the atmosphere and the geographical distribution of $\mathrm{Hg}$ deposition. Using the latest version of the Global Fire Emissions Database (GFEDv4.1s) and the global $\mathrm{Hg}$ chemistry transport model, ECHMERIT, the impact of $\mathrm{Hg}$ speciation in BB emissions, and the factors which influence speciation, on $\mathrm{Hg}$ deposition have been investigated for the year 2013. The role of other uncertainties related to physical and chemical atmospheric processes involving $\mathrm{Hg}$ and the influence of model parametrisations were also investigated, since their
\end{abstract}

interactions with $\mathrm{Hg}$ speciation are complex. The comparison with atmospheric $\mathrm{Hg}^{\mathrm{P}}$ concentrations observed at two remote sites, Amsterdam Island (AMD) and Manaus (MAN), in the Amazon showed a significant improvement when considering a fraction of $\mathrm{Hg}^{\mathrm{P}}$ from $\mathrm{BB}$. The set of sensitivity runs also showed how the quantity and geographical distribution of $\mathrm{Hg}^{\mathrm{P}}$ emitted from $\mathrm{BB}$ has a limited impact on a global scale, although the inclusion of increasing fractions $\mathrm{Hg}^{\mathrm{P}}$ does limit $\mathrm{Hg}_{(\mathrm{g})}^{0}$ availability to the global atmospheric pool. This reduces the fraction of $\mathrm{Hg}$ from $\mathrm{BB}$ which deposits to the world's oceans from 71 to $62 \%$. The impact locally is, however, significant on northern boreal and tropical forests, where fires are frequent, uncontrolled and lead to notable $\mathrm{Hg}$ inputs to local ecosystems. In the light of ongoing climatic changes this effect could be potentially be exacerbated in the future. 


\section{Introduction}

Emissions from biomass burning (BB) are an important source of mercury $(\mathrm{Hg})$ to the atmosphere (De Simone et al., 2015; Friedli et al., 2009) and a major factor in determining the interannual variations of its tropospheric concentration (Slemr et al., 2016). Although the Hg released by BB varies from year to year, it can amount to up to roughly one third of the anthropogenic emission estimates (AMAP/UNEP, 2013; Friedli et al., 2009; De Simone et al., 2015). With the eventual implementation of the Minamata Convention (http:// www.mercuryconvention.org/) and future curbs on industrial emission, as a by-product of industrial emission abatement measures, its relative importance will increase in the coming years. A previous modelling study (De Simone et al., 2015) used the global $\mathrm{Hg}$ chemistry model, ECHMERIT, and three $\mathrm{BB}$ inventories to assess the distribution of $\mathrm{Hg}$ deposition resulting from $\mathrm{BB}$. A large part of the $\mathrm{Hg}$ released from $\mathrm{BB}$ deposits over oceans, where its re-emission is driven by sea surface temperature, among other factors (Carbone et al., 2016; Andersson et al., 2011), or where it can be converted to toxic methyl mercury (MeHg) compounds, has important implications for the food web and, through fish consumption, also for human health (see Chen et al., 2016, and references therein). The deposition flux of $\mathrm{Hg}$ from $\mathrm{BB}$ has been shown to be more sensitive to certain factors, in particular the chemical mechanism employed in the model and the choice of emission inventory, than to others such as the vertical profiles of emissions (De Simone et al., 2015). In this previous study all $\mathrm{Hg}$ emitted from $\mathrm{BB}$ was considered to be $\mathrm{Hg}_{(\mathrm{g})}^{0}$. There is, however, evidence that the fraction of $\mathrm{Hg}$ emitted bound to particulates $\left(\mathrm{Hg}^{\mathrm{P}}\right)$ may be sizeable, up to $30 \%$, especially when the fuel moisture content (FMC) is high (Obrist et al., 2007; Finley et al., 2009; Friedli et al., 2009; Wang et al., 2010). These levels, however, remain uncertain since different methodologies have led to different conclusions (Zhang et al., 2013; Obrist et al., 2007). Little is known about the mechanisms that control the speciation of $\mathrm{Hg}$ in $\mathrm{BB}$ emissions, which leads to uncertainties in the $\mathrm{Hg}$ deposition patterns, since the atmospheric lifetime of $\mathrm{Hg}^{\mathrm{P}}$ is significantly shorter than $\mathrm{Hg}_{(\mathrm{g})}^{0}$, leading to greater local deposition. Local $\mathrm{Hg}$ deposition due to $\mathrm{BB}$ could have important repercussions in regions such as the South-East Asia, where there is intensive rice cultivation, which is subject to major BB events, especially during El Niño periods. Hg deposited to rice paddies can be readily converted to toxic $\mathrm{MeHg}$ that can accumulate in the grains (Wang et al., 2015; Feng et al., 2008; Meng et al., 2014; Zhang et al., 2010). Moreover, it has been reported that $\mathrm{Hg}^{\mathrm{P}}$ from $\mathrm{BB}$ deposited to foliage has the ability to enhance MeHg formation (Witt et al., 2009). The aim of this study is to investigate the effects on simulated deposition fluxes of $\mathrm{Hg}$ resulting from $\mathrm{BB}$ when variations in $\mathrm{Hg}^{\mathrm{P}}$ fraction and production processes are considered. The most recent version of the GFED BB emission inventory (van der Werf et al., 2010; Randerson et al., 2012; Mu et al., 2011), has been included in the global online $\mathrm{Hg}$ chemical transport model ECHMERIT to simulate $\mathrm{Hg}$ deposition from BB for the year 2013 and to quantify the influence of variations in model inputs, assumptions and parametrisations.

\section{Methods}

\subsection{The biomass burning inventory}

The reference BB inventory in this study, Global Fire Emissions Database version 4 (GFED4.1s), is based on an updated version of the inventory of van der Werf et al. (2010) with burned area from Giglio et al. (2013), and with the addition of small fire-burned area (Randerson et al., 2012). The standard temporal resolution of the emissions files is monthly, but data are provided to distribute these daily, and a diurnal cycle based on $\mathrm{Mu}$ et al. (2011) is also available. Daily BB emissions from two other global inventories, GFASv1.2 (Kaiser et al., 2012, 2015) and FINNv1.5 (Wiedinmyer et al., 2011), were also included in the model for sensitivity runs. These three inventories are all compiled using the imagery obtained from the MODIS instruments. However, the way in which the data are filtered or processed yields substantial differences between the final products; see Andela et al. (2013) and references therein for a detailed description of the differences among the inventories.

\subsection{Experimental set-up}

The global Hg chemical transport model ECHMERIT (Jung et al., 2009; De Simone et al., 2014) uses T42 horizontal resolution (roughly $2.8^{\circ}$ by $2.8^{\circ}$ at the Equator) and 19 vertical levels up to $10 \mathrm{hPa}$. $\mathrm{Hg}$ emissions from $\mathrm{BB}$ were included in the model by mapping them to $\mathrm{CO}$ emissions using the global averaged enhancement ratio (ER) of $1.96 \times 10^{-7}$, as obtained by Friedli et al. (2009), averaging field measurements from different biomes in various regions around the globe, including in plume measurements from the CARIBIC project (Ebinghaus et al., 2007). Previous modelling studies have used different ERs (De Simone et al., 2015; Holmes et al., 2010), but all these values were well within the range of uncertainty $\left(0.3-6.0 \times 10^{-7}\right.$; see Wang et al., 2015). ECHMERIT, in the base configuration, includes the oxidation of $\mathrm{Hg}_{(\mathrm{g})}^{0}$ to in $\mathrm{Hg}_{(\mathrm{g} / \mathrm{aq})}^{\mathrm{II}}$ oxidation by $\mathrm{O}_{3} / \mathrm{OH}$ in the gas and aqueous phases. $\mathrm{OH}$ and $\mathrm{O}_{3}$ concentration fields were imported from MOZART (Model for Ozone and Related chemical Tracers) (Emmons et al., 2010). $\mathrm{Hg}^{\mathrm{P}}$ is assumed to be inert, whether it is emitted from anthropogenic activities or $\mathrm{BB}$, and it is subject to transport and deposition processes but is not involved in any chemical reactions. Mechanisms and parametrisations used for calculating the dry and the wet deposition of the different $\mathrm{Hg}$ species are the same as described in Jung et al. (2009). Beyond this standard configuration a number of alternative processes and chemical mechanisms have been considered for this study, as explained in 
Sect. 2.3. Atmospheric reduction of $\mathrm{Hg}_{(\mathrm{g} / \mathrm{aq})}^{\mathrm{II}}$ to $\mathrm{Hg}_{(\mathrm{g})}^{0}$ has been included in many models to regulate the residence time of $\mathrm{Hg}_{(\mathrm{g})}^{0}$ in the atmosphere. However, a number of the proposed mechanisms are unlikely to occur under most atmospheric conditions or are based on empirical rates to better match the observations (see Kwon and Selin (2016) for a recent review). Due to this uncertainty, reduction was not included in this study. No further $\mathrm{Hg}^{\mathrm{P}}$ particulate matter (PM) dimension distributions other than the standard log-normal particle size distribution, as described in detail in (Jung et al., 2009), were considered in this study due to large uncertainties regarding the dynamic size range of PM emitted during BB (see Janhäll et al. (2010) and references therein). GFED4.1s provides monthly burned area, fire carbon (C) and dry matter (DM) emissions (http://www.falw.vu/ gwerf/ GFED/GFED4/). A script is provided to derive gaseous and PM emissions from DM fields making use of biome-based emission factors based on Akagi et al. (2011) and van der Werf et al. (2010). The resulting emission fields were then interpolated on to the ECHMERIT T42 grid using the mass conserving remapping function included in the Climate Data Operators (https://code.zmaw.de/projects/cdo).

\subsection{Simulations and their scope}

The BASE simulation used as the reference case in this study includes daily BB emissions from GFEDv4.1s, in which a global uniform fraction of $\mathrm{Hg}^{\mathrm{P}}$, equal to $15 \%$ of the total $\mathrm{Hg}$ emission is assumed. This value is within the range of observations (Obrist et al., 2007; Finley et al., 2009). However, since there are uncertainties in the proportion of $\mathrm{Hg}^{\mathrm{P}}$ emitted from BB (Zhang et al., 2013), further simulations were carried out with varying fractions of $\mathrm{Hg}^{\mathrm{P}}(0,4$ and $30 \%)$. Simulations were also conducted mapping the $15 \%$ of the total $\mathrm{Hg}$ emitted as $\mathrm{Hg}^{\mathrm{P}}$ to the geographical distribution of different proxy chemical species (see Sect. 2.4). The shorter lifetime of $\mathrm{Hg}^{\mathrm{P}}$ with respect to $\mathrm{Hg}_{(\mathrm{g})}^{0}$ potentially means that the vertical profile of the emissions could have an impact on the distribution of $\mathrm{Hg}$ deposition, as is the case for other speciated Hg emission sources (De Simone et al., 2016). Therefore two vertical profile parametrisations, as well as different emission injection time resolutions, were also included in the study. The principal vertical profile used (PBL-Profile) maps the $\mathrm{Hg}$ emissions uniformly within the planetary boundary layer (PBL), whereas in the second the vertical profile of the standard version of the ECHAM-HAM model was used (HAM-Profile) (Zhang et al., 2012). The HAM-Profile is equal to PBL-Profile when the PBL height is greater than $4000 \mathrm{~m}$; otherwise $75 \%$ of the emissions are placed within the PBL and the remainder in the two layers above the PBL (17 and $8 \%$ ). This threshold value is arbitrary, but it is the standard configuration of ECHAM6-HAM2 (Zhang et al., 2012; Veira et al., 2015). Biomass burning emissions from GFASv1.2 (Kaiser et al., 2012, 2015) and FINNv1.5 (Wiedinmyer et al., 2011) were also used in the study to assess uncertainty related to the satellite imagery processing and inventory compilation. Simulations using GFASv1.2 were excluded from suqsequent analyses since the low $\mathrm{Hg}$ emissions could be due to a technical problem arising from GRIB encoding (see GFAS, 2015). These simulations primarily employ a $\mathrm{O}_{3} / \mathrm{OH} \mathrm{Hg}_{(\mathrm{g})}^{0}$ oxidation mechanism. However, since the precise atmospheric $\mathrm{Hg}$ oxidation mechanism remains unclear (Hynes et al., 2009; Subir et al., 2011, 2012; Gustin and Jaffe, 2010; Gustin et al., 2015; Ariya et al., 2015), a number of runs were performed using a Br-based oxidation mechanism. Some studies (Steffen et al., 2014; Amos et al., 2012) suggest that the partitioning of reactive $\mathrm{Hg}$ species the between gas and particulate phases might be driven by air temperature and on the surface are of the aerosol present in the atmosphere. Therefore, two other simulations weer conducted including the temperature-dependent gas-particle partitioning described in Amos et al. (2012), one assuming BB $\mathrm{Hg}$ emissions to be only $\mathrm{Hg}_{(\mathrm{g})}^{0}$ and another assuming a $15 \%$ of $\mathrm{BB} \mathrm{Hg}$ emissions to be $\mathrm{Hg}^{\mathrm{P}}$. To estimate the ratio of $\mathrm{Hg}$ deposition from $\mathrm{BB}$ compared to anthropogenic sources, six further simulations were conducted including only anthropogenic emissions using the EDGAR (Muntean et al., 2014), AMAP2010 (AMAP/UNEP, 2013) and STREETS (Corbitt et al., 2011) inventories, employing the $\mathrm{O}_{3} / \mathrm{OH}$ and $\mathrm{Br}$ oxidation mechanisms. This study covers a single year, 2013, chosen due to the availability of measurements from GMOS network (Sprovieri et al., 2016a, b; D'Amore et al., 2015). All simulations were performed for a full year, without the rapid re-emission mechanism (Selin et al., 2008), and were continued without further emissions for another 12 months to allow most of the $2013 \mathrm{Hg}$ emissions to be deposited. Finally, a selection of simulations were re-run including $\mathrm{Hg}$ emissions from all sources, BB, anthropogenic emissions from AMAP2010 (AMAP/UNEP, 2013), dynamic ocean emissions, terrestrial emissions and re-emissions as described in De Simone et al. (2014), to evaluate model performance against measurements and to evaluate the assumptions made in this study. A summary of the simulations performed can be found in Table 1 .

\subsection{BB emission speciation}

The release of $\mathrm{Hg}$ from $\mathrm{BB}$ occurs prevalently as $\mathrm{Hg}_{(\mathrm{g})}^{0}$. However, as mentioned previously, a measurable fraction may be emitted as $\mathrm{Hg}^{\mathrm{P}}$ (Obrist et al., 2007; Friedli et al., 2009; Finley et al., 2009; Wang et al., 2010). No significant amounts of gaseous oxidised $\mathrm{Hg}\left(\mathrm{Hg}_{(\mathrm{g})}^{\mathrm{II}}\right)$ have so far been detected in BB emissions (Obrist et al., 2007, and references therein). The speciation of $\mathrm{Hg}$ emissions is of great importance, since it largely determines the atmospheric lifetime and hence the distance emitted $\mathrm{Hg}$ is transported in the atmosphere before deposition, as seen for other speciated $\mathrm{Hg}$ sources (Bieser et al., 2014). The fraction of $\mathrm{Hg}^{\mathrm{P}}$ released by BB determined in field and laboratory studies ranges from fractions of a few percent to over $30 \%$ (Obrist et al., 2007). The factors deter- 
Table 1. Simulations performed.

\begin{tabular}{|c|c|c|c|c|c|c|c|c|}
\hline Name & Inventory (BB emission $(\mathrm{Mg})$ ) & Full version & Emiss. time res. & Fraction $\mathrm{Hg}^{\mathrm{P}}(\%)$ & Map $\mathrm{Hg}^{\mathrm{P}}$ & Chem. mech. & Vertical profile & Scope \\
\hline BASE & GFED4.1s (390) & Yes & daily & 15 & $\mathrm{CO}$ & $\mathrm{O}_{3} / \mathrm{OH}$ & PBL & Reference \\
\hline 3-hourly & GFED4.1s (390) & & $3 \mathrm{~h}$ & 15 & $\mathrm{CO}$ & $\mathrm{O}_{3} / \mathrm{OH}$ & PBL & Emiss. time resol. \\
\hline Monthly & GFED4.1s (390) & & monthly & 15 & $\mathrm{CO}$ & $\mathrm{O}_{3} / \mathrm{OH}$ & PBL & Emiss. time resol. \\
\hline HAM-Profile & GFED4.1s (390) & & daily & 15 & $\mathrm{CO}$ & $\mathrm{O}_{3} / \mathrm{OH}$ & HAM & Vertical profile \\
\hline Only first level & GFED4.1s (390) & & daily & 15 & $\mathrm{CO}$ & $\mathrm{O}_{3} / \mathrm{OH}$ & $1 \mathrm{st}$ & Vertical profile \\
\hline Only PBL level & GFED4.1s (390) & & daily & 15 & $\mathrm{CO}$ & $\mathrm{O}_{3} / \mathrm{OH}$ & level of PBL & Vertical profile \\
\hline $3 \mathrm{~h}+$ HAM-prof & GFED4.1s (390) & & daily & 15 & $\mathrm{CO}$ & $\mathrm{O}_{3} / \mathrm{OH}$ & HAM & V. Pr. \& E. T. res. \\
\hline $\mathrm{Hg}^{\mathrm{P}}$ to $\mathrm{PM}$ & GFED4.1s (390) & Yes & daily & 15 & PM & $\mathrm{O}_{3} / \mathrm{OH}$ & PBL & $\mathrm{Hg}^{\mathrm{P}}$ mapping \\
\hline $\mathrm{Hg}^{\mathrm{P}}$ to $\mathrm{OC}$ & GFED4.1s (390) & Yes & daily & 15 & OC & $\mathrm{O}_{3} / \mathrm{OH}$ & PBL & $\mathrm{Hg}^{\mathrm{P}}$ mapping \\
\hline $\mathrm{Hg}^{\mathrm{P}}$ to FMC & GFED4.1s (390) & Yes & daily & variable & $\mathrm{CO}$ & $\mathrm{O}_{3} / \mathrm{OH}$ & PBL & $\mathrm{Hg}^{\mathrm{P}}$ mapping \\
\hline $\mathrm{NO} \mathrm{Hg}{ }^{\mathrm{P}}$ & GFED4.1s (390) & Yes & daily & 0 & NA & $\mathrm{O}_{3} / \mathrm{OH}$ & PBL & Fraction $\mathrm{Hg}^{\mathrm{P}}$ \\
\hline $4 \% \mathrm{Hg}^{\mathrm{P}}$ & GFED4.1s (390) & & daily & 4 & $\mathrm{CO}$ & $\mathrm{O}_{3} / \mathrm{OH}$ & PBL & Fraction $\mathrm{Hg}^{\circ}$ \\
\hline $30 \% \mathrm{Hg}^{\mathrm{P}}$ & GFED4.1s (390) & Yes & daily & 30 & $\mathrm{CO}$ & $\mathrm{O}_{3} / \mathrm{OH}$ & PBL & Fraction $\mathrm{Hg}^{\mathrm{P}}$ \\
\hline $100 \% \mathrm{Hg}^{\mathrm{P}}$ & GFED4.1s (390) & & daily & 100 & $\mathrm{CO}$ & None & PBL & Transport $\mathrm{Hg}^{\mathrm{P}}$ \\
\hline Partitioning & GFED4.1s (390) & Yes & daily & 15 & $\mathrm{CO}$ & $\mathrm{O}_{3} / \mathrm{OH}$ & PBL & Partitioning $\mathrm{Hg}^{\mathrm{P}} / \mathrm{II}$ \\
\hline Partitioning ref. & GFED4.1s (390) & Yes & daily & 0 & $\mathrm{CO}$ & $\mathrm{O}_{3} / \mathrm{OH}$ & PBL & Partitioning $\mathrm{Hg}^{\mathrm{P}} / \mathrm{II}$ \\
\hline Reduction & GFED4.1s (390) & Yes & daily & 15 & $\mathrm{CO}$ & $\mathrm{O}_{3} / \mathrm{OH}+$ Red. & PBL & Chemistry \\
\hline $\mathrm{Br}$ & GFED4.1s (390) & Yes & daily & 15 & $\mathrm{CO}$ & $\mathrm{Br}$ & PBL & Chemistry \\
\hline $\mathrm{Br}$ No $\mathrm{Hg}^{\mathrm{P}}$ & GFED4.1s (390) & & daily & 0 & NA & $\mathrm{Br}$ & PBL & Chemistry \\
\hline $\mathrm{Br} 30 \% \mathrm{Hg}^{\mathrm{P}}$ & GFED4.1s (390) & & daily & 30 & $\mathrm{CO}$ & $\mathrm{Br}$ & PBL & Chemistry \\
\hline $\mathrm{Br} \mathrm{Hg}{ }^{\mathrm{P}}$ to $\mathrm{OC}$ & GFED4.1s (390) & & daily & 15 & $\mathrm{OC}$ & $\mathrm{Br}$ & PBL & Chemistry \\
\hline $\mathrm{Br} \mathrm{Hg}^{\mathrm{P}}$ to $\mathrm{FMC}$ & GFED4.1s (390) & & daily & variable & $\mathrm{CO}$ & $\mathrm{Br}$ & PBL & Chemistry \\
\hline GFAS & GFASv1.2 (150; see Sect. 2.3) & & daily & 15 & $\mathrm{CO}$ & $\mathrm{O}_{3} / \mathrm{OH}$ & PBL & Inventory \\
\hline GFAS Br & GFASv1.2 (150; see Sect. 2.3) & & daily & 15 & $\mathrm{CO}$ & $\mathrm{Br}$ & PBL & Chemistry \\
\hline FINN & FINNv1.5 (550) & Yes & daily & 15 & $\mathrm{CO}$ & $\mathrm{O}_{3} / \mathrm{OH}$ & PBL & Inventory \\
\hline FINN Br & FINNv1.5 (550) & & daily & 15 & $\mathrm{CO}$ & $\mathrm{Br}$ & PBL & Chemistry \\
\hline AMAPOH & AMAP2010 & & NA & NA & NA & $\mathrm{O}_{3} / \mathrm{OH}$ & NA & Ratio to anth. emiss. \\
\hline AMAPBr & AMAP2010 & & NA & NA & NA & $\mathrm{Br}$ & NA & Ratio to anth. emiss. \\
\hline EDGAROH & EDGAR2008 & & NA & NA & NA & $\mathrm{O}_{3} / \mathrm{OH}$ & NA & Ratio to anth. emiss. \\
\hline EDGARBr & EDGAR2008 & & NA & NA & NA & $\mathrm{Br}$ & NA & Ratio to anth. emiss. \\
\hline STREETSOH & STREETS2005 & & NA & NA & NA & $\mathrm{O}_{3} / \mathrm{OH}$ & NA & Ratio to anth. emiss. \\
\hline STREETSBr & STREETS2005 & & NA & NA & NA & $\mathrm{Br}$ & NA & Ratio to anth. emiss. \\
\hline
\end{tabular}

mining speciation and whether $\mathrm{Hg}^{\mathrm{P}}$ is directly emitted or if it is the product of the oxidation of $\mathrm{Hg}_{(\mathrm{g})}^{0}$ within the plume (Obrist et al., 2007; Webster et al., 2016) are not known. However, foliage, moisture content, fuel type, plant species and combustion proprieties certainly play a role. $\mathrm{Hg}^{\mathrm{P}}$ emissions were found to be well correlated with particulate matter (PM) and organic carbon (OC) emissions (Obrist et al., 2007). Obrist et al. (2007) found that $\mathrm{Hg}_{(\mathrm{g})}^{0}$ is the dominant species in dry fuel combustion, whereas the fraction of $\mathrm{Hg}^{\mathrm{P}}$ becomes appreciable when FMC reaches roughly $30 \%$, above which $\mathrm{Hg}^{\mathrm{P}}$ release appears to increase linearly with FMC. In the inventory used for the BASE case both $\mathrm{Hg}_{(\mathrm{g})}^{0}$ and $\mathrm{Hg}^{\mathrm{P}}$ follow the spatial distribution of $\mathrm{CO}$ emissions from $\mathrm{BB}$, and $15 \%$ of the emitted $\mathrm{Hg}$ is considered to be $\mathrm{Hg}^{\mathrm{P}}$ (see Figs. 1a and 2a). $\mathrm{Hg}$ emission fields were also compiled in which the $\mathrm{Hg}^{\mathrm{P}}$ fraction of the total $\mathrm{Hg}$ emitted was mapped to OC and PM emissions (see Fig. 2b and c). A further emission field was compiled in which the ratio of $\mathrm{Hg}_{(\mathrm{g})}^{0}$ to $\mathrm{Hg}^{\mathrm{P}}$ is determined by the FMC (Figs. 1b and 2d). A relationship was found to exist between $\mathrm{Hg}^{\mathrm{P}}$ emissions and the fire burn duration and severity as well as combustion conditions (Obrist et al., 2007; Webster et al., 2016). In particular high $\mathrm{Hg}^{\mathrm{P}}$ fractions were observed during smouldering phases, whereas very low or undetectable $\mathrm{Hg}^{\mathrm{P}}$ levels were found during flaming combustion. These potential parametrisations were not investigated here due to the difficulty in finding a suitable proxy data set. Appendix A contains a more detailed description of the methods used to calculate the different $\mathrm{Hg} \mathrm{BB}$ emission fields.

\section{Results}

\subsection{Emissions}

The total $\mathrm{Hg}$ emitted in 2013 based on the GFED inventory is roughly $400 \mathrm{Mg}$, which is at the lower end of the initial estimates $(675 \pm 240 \mathrm{Mg})$ (Friedli et al., 2009) but is reasonable considering the natural variation of BB activity and the diminishing trend of the $\mathrm{CO}$ emission estimates in the latest inventory revisions (up to $50 \%$ for some years) (van der Werf et al., 2010). Considering $15 \%$ of the emissions to be $\mathrm{Hg}^{\mathrm{P}}$, in the BASE run this corresponds to approximately $340 \mathrm{Mg}$ $\mathrm{Hg}_{(\mathrm{g})}^{0}$ and $60 \mathrm{Mg} \mathrm{Hg}^{\mathrm{P}}$. Interestingly the emissions of $\mathrm{Hg}^{\mathrm{P}}$ amount to $58 \mathrm{Mg}$ when relating the $\mathrm{Hg}^{\mathrm{P}}$ fraction to FMC. The exact amount of $\mathrm{Hg}$ emitted by BB in the different model runs is detailed in Table 1 . The spatial distribution and the vertical profile of the emission injection height, considering the PBL-Profile for $\mathrm{Hg}_{(\mathrm{g})}^{0}$ and $\mathrm{Hg}^{\mathrm{P}}$ in the different cases considered are shown in Figs. 1 and 2. Both the geographical and vertical distributions of the emissions of the $\mathrm{Hg}$ species reveal notable differences depending on the methodology used, particularly for $\mathrm{Hg}^{\mathrm{P}}$. Compared to the cases where $\mathrm{Hg}^{\mathrm{P}}$ emis- 
(a)

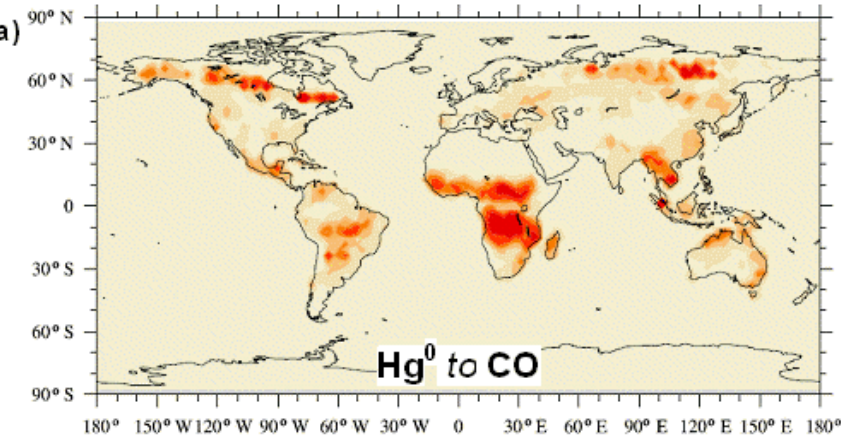

(b)

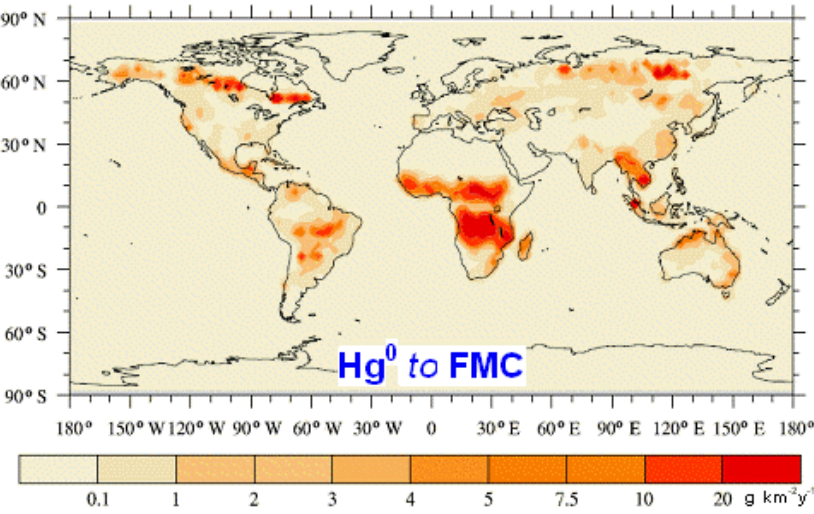

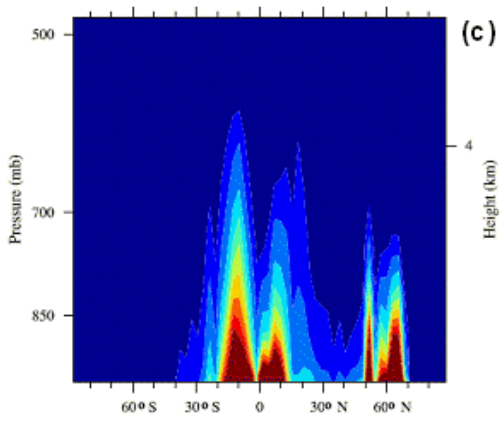

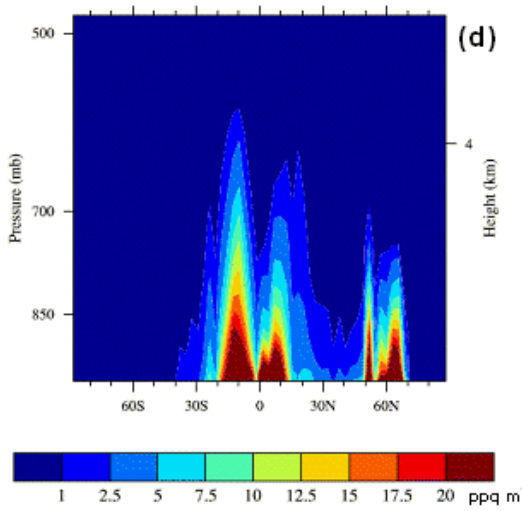

Figure 1. Geographical distribution (a-b) and PBL-type vertical profiles (c-d) of the $\mathrm{Hg}_{(\mathrm{g})}^{0}$ emissions, when mapped to CO (a, c) and when speciation is determined by FMC (b, d). For the emissions mapped to CO, only the speciation $\left(15: 85 \mathrm{Hg}^{\mathrm{P}}: \mathrm{Hg}_{(\mathrm{g})}^{0}\right)$ is shown for clarity.

sions are mapped to CO and PM (Fig. 2a-b and e-f), mapping $\mathrm{Hg}^{\mathrm{P}}$ to $\mathrm{OC}$ and using the $\mathrm{FMC}$ to determine the speciation (Fig. $2 \mathrm{c}-\mathrm{d}$ and $\mathrm{g}-\mathrm{h}$ ) result in enhanced $\mathrm{Hg}^{\mathrm{P}}$ emissions, above $60^{\circ} \mathrm{N}$ and over some areas the Amazon, central Africa and East Asia as evident in Fig. 3. The timing and location of the enhanced $\mathrm{Hg}^{\mathrm{P}}$ emission at northerly latitudes could be particularly relevant for $\mathrm{Hg}$ deposition to the Arctic. From Fig. 3 it is evident how the geographical distribution of the $\mathrm{Hg}^{\mathrm{P}}$ to $\mathrm{Hg}_{(\mathrm{g})}^{0}$ emission ratio differs with the assumptions considered. However, for OC and FMC there is general agreement on the areas where the $\mathrm{Hg}^{\mathrm{P}}$ emissions are relatively higher, especially in the Northern Hemisphere and particularly for areas above $60^{\circ} \mathrm{N}$. The agreement between OC and FMC is not surprising and is related to the combustion characteristics that enhance $\mathrm{OC}$ emissions, i.e. lower combustion temperatures and the dominance of the smouldering phase of combustion (Zhang et al., 2013), that are likely to occur where FMC is greatest.

\subsection{Emission latitudinal profiles}

The latitudinal profiles of $\mathrm{Hg}_{(\mathrm{g})}^{0}$ and $\mathrm{Hg}^{\mathrm{P}}$ emissions, using the different approaches (Sect. 2.4), are shown in Fig. 4a and $\mathrm{b}$. For those emissions mapped to CO, only the $15: 85$ $\left(\mathrm{Hg}^{\mathrm{P}}: \mathrm{Hg}_{(\mathrm{g})}^{\mathrm{O}}\right)$ speciation is reported for clarity. The differences in the latitudinal profiles of the $\mathrm{Hg}_{(\mathrm{g})}^{0}$ emissions
(Fig. 4a) are sizeable only for the peaks north of $45^{\circ} \mathrm{N}$, where the FMC-based speciation has an $\mathrm{Hg}_{(\mathrm{g})}^{0}$ fraction below $85 \%$. The latitudinal profiles of $\mathrm{Hg}^{\mathrm{P}}$ emissions mapped to $\mathrm{PM}$ and CO look very similar over the entire domain (Fig. 4b), apart from a peak a few degrees north of the Equator. The $\mathrm{Hg}^{\mathrm{P}}$ emissions mapped to OC and FMC differ from the PM and $\mathrm{CO}$ profiles but are similar to each other between roughly $30^{\circ} \mathrm{S}$ and $60^{\circ} \mathrm{N}$. South of $30^{\circ} \mathrm{S} \mathrm{Hg}^{\mathrm{P}}$ emissions mapped to OC are higher, while peak $\mathrm{Hg}^{\mathrm{P}}$ emissions derived from FMC at $65^{\circ} \mathrm{N}\left(1.5 \mathrm{~g} \mathrm{~km}^{-2} \mathrm{yr}^{-1}\right)$ are nearly $30 \%$ greater than those derived from $\mathrm{OC}$ and roughly double those mapped to $\mathrm{CO}$ and PM. Moreover, in the FMC scenario the peak in $\mathrm{Hg}^{\mathrm{P}}$ emissions at $65^{\circ} \mathrm{N}$ are greater than the peak seen at $15^{\circ} \mathrm{S}(1.5$ vs. $\left.1.4 \mathrm{~g} \mathrm{~km}^{-2} \mathrm{yr}^{-1}\right)$. As is particularly evident in Fig. $4 \mathrm{c}$, the most notable differences among the different assumptions hypothesised are above $60^{\circ} \mathrm{N}$, where both the OC and the FMC cases agree on the location of the greatest $\mathrm{Hg}^{\mathrm{P}}$ emissions probably due to the linkage between $\mathrm{OC}$ emissions and combustion processes favoured by FMC (Zhang et al., 2013), and between 30 and $45^{\circ} \mathrm{S}$, where only OC and PM are greater than BASE. A previous modelling study focusing on the fate of $\mathrm{Hg}$ from $\mathrm{BB}$, where all emissions were considered as $\mathrm{Hg}_{(\mathrm{g})}^{0}$, showed that the long atmospheric life of the elemental $\mathrm{Hg}$ smoothed the deposition latitudinal profiles compared to the emission profiles (De Simone et al., 2015). The four panels in Fig. 5 compare the normalised lati- 
(a)

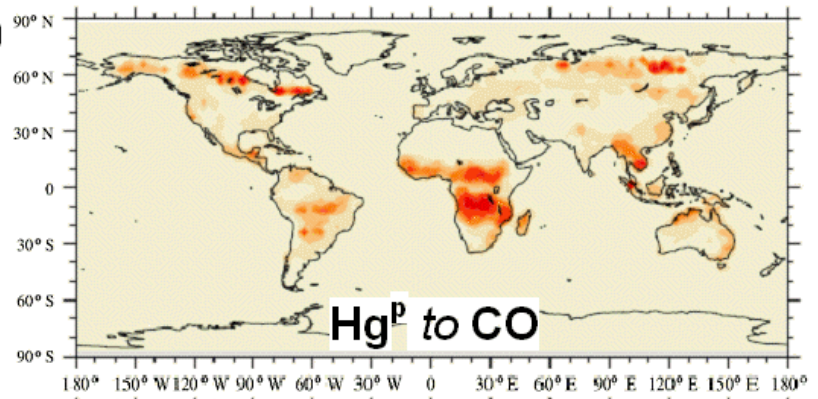

(b)

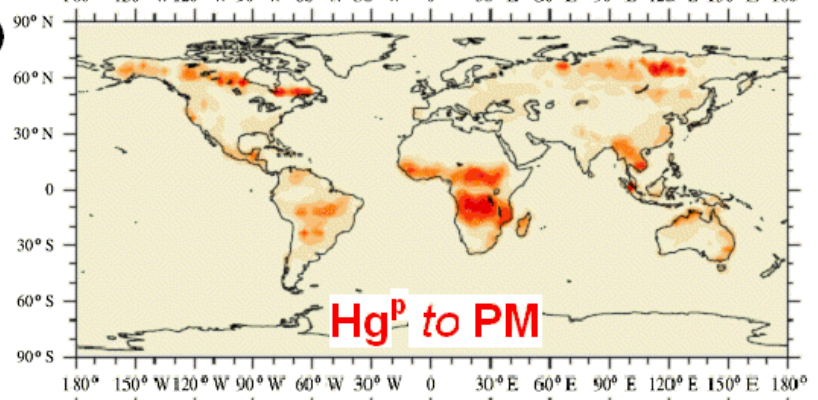

(c)

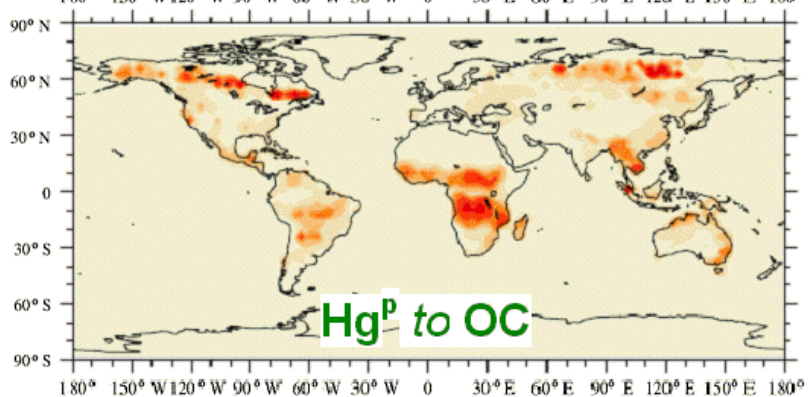

(d)

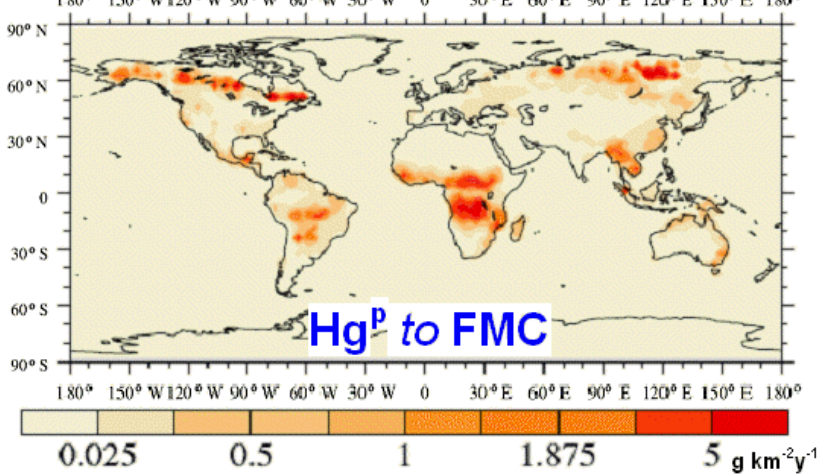

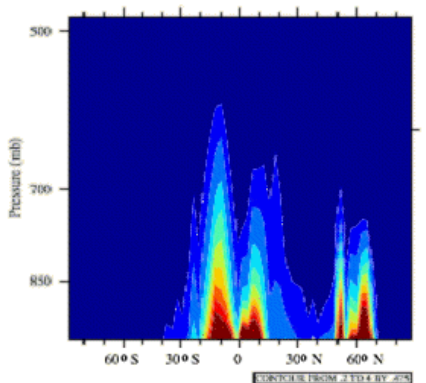

(e)

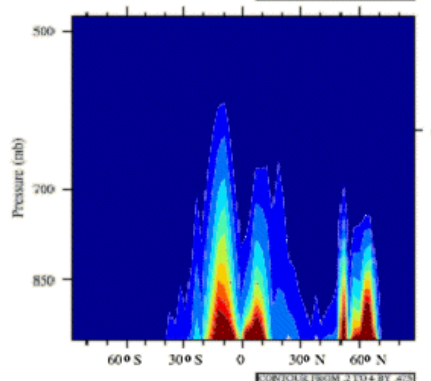

(f)
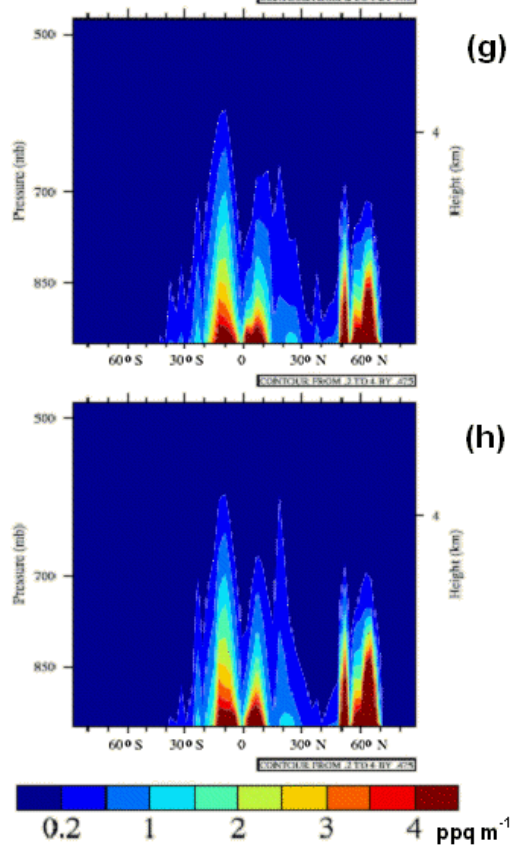

Figure 2. Geographical distribution (a-d) and PBL-type vertical profiles (e-h) of the $\mathrm{Hg}^{\mathrm{P}}$ emissions as injected in the model, when mapped to $\mathrm{CO}(\mathbf{a}, \mathbf{e}), \mathrm{PM}(\mathbf{b}, \mathbf{f})$ and $\mathrm{OC}(\mathbf{c}, \mathbf{g})$ and when speciation is determined by FMC $(\mathbf{d}, \mathbf{h})$. For the emissions mapped to CO, only the speciation $\left(15: 85 \mathrm{Hg}^{\mathrm{P}}: \mathrm{Hg}_{(\mathrm{g})}^{0}\right)$ is shown for clarity.

tudinal deposition profiles obtained for the BASE simulation with those obtained from the alternative $\mathrm{Hg}^{\mathrm{P}}$ emission scenarios by category. Figure 5a demonstrates the very limited impact of the time resolution used for BB emissions, most likely due to the coarse horizontal resolution of the model. The two vertical emission profiles (Fig. 5b) give deposition fields that are to all effects indistinguishable, even when considering varying temporal resolution of the $\mathrm{BB}$ emissions, whereas assuming all emissions to be in the first model level (with an average height of approximately $35 \mathrm{~m}$ ) leads to enhanced deposition near emission peaks. In this instance, the maximum deposition coincides with peak emission, at approximately $15^{\circ} \mathrm{S}$, whereas in all other cases maximum deposition is shifted towards the Equator.

The similarities in the latitudinal profiles of $\mathrm{Hg}^{\mathrm{P}}$ emissions when mapped to $\mathrm{CO}$ and PM are reflected in their deposition profiles (Fig. 5c). The relatively greater deposition north of $60^{\circ} \mathrm{N}$ seen in Fig. 5c, obtained when $\mathrm{Hg}^{\mathrm{P}}$ emissions are 

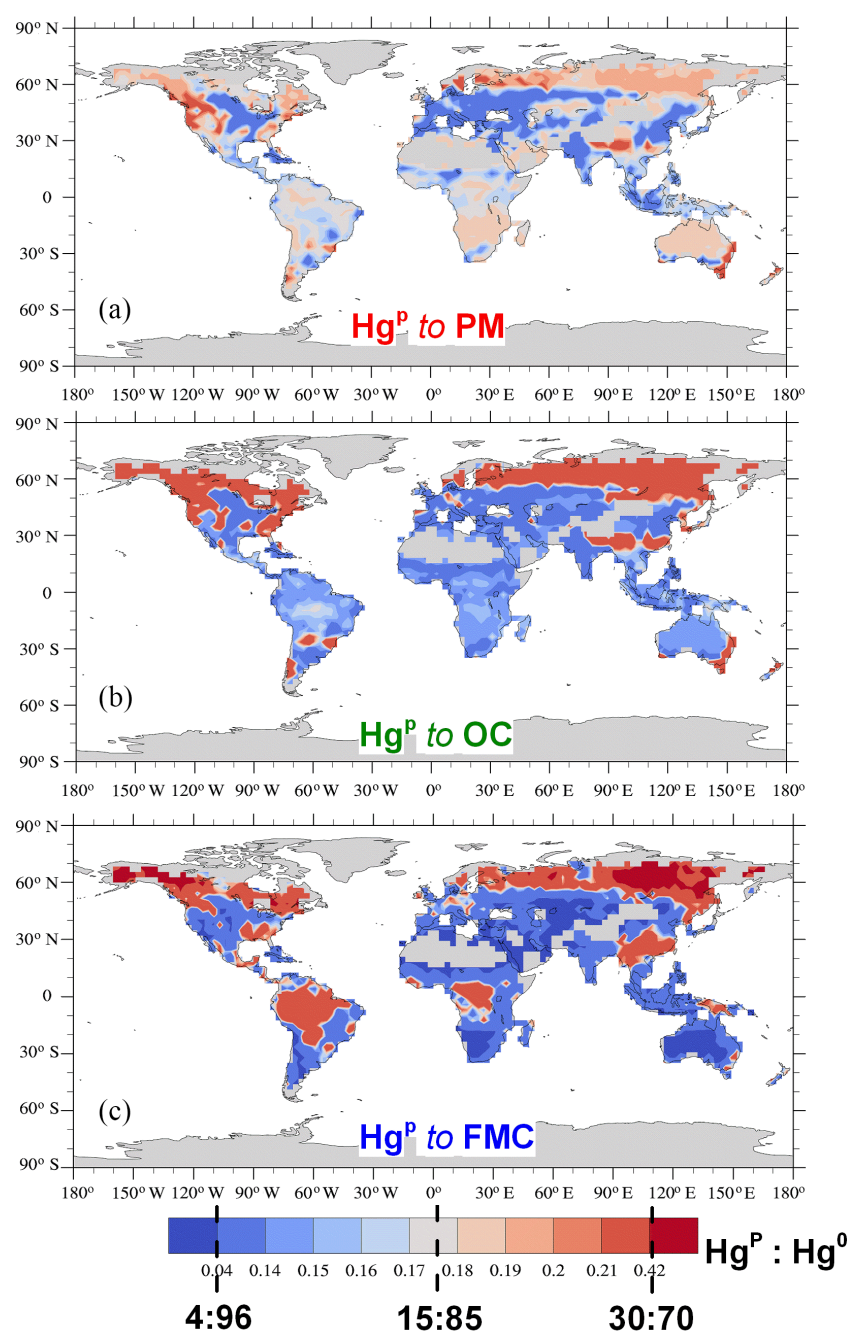

Figure 3. Geographical distribution of the $\mathrm{Hg}^{\mathrm{P}}: \mathrm{Hg}_{(\mathrm{g})}^{0}$ emissions ratio, when mapped to PM (a) and OC (b) and when speciation is determined by FMC (c). In the colour bar the levels corresponding to the constant speciations $\left(4: 96,15: 85\right.$ and $\left.30: 70 \mathrm{Hg}^{\mathrm{P}}: \mathrm{Hg}_{(\mathrm{g})}^{0}\right)$ used for the emissions mapped to $\mathrm{CO}$ are indicated.

mapped to OC and when driven by FMC, reflects the peak in $\mathrm{Hg}^{\mathrm{P}}$ emissions at this latitude. The greatest differences in the latitudinal deposition profiles, using the GFED inventory, are seen when varying the percentage of $\mathrm{Hg}^{\mathrm{P}}$ in the emissions (Fig. 5d). Considering emissions to be solely $\mathrm{Hg}_{(\mathrm{g})}^{0}$ yields a relatively smooth profile extending from pole to pole, increasing $\mathrm{Hg}^{\mathrm{P}}$ causes enhanced deposition near BB hotspots. The emission peak at around $50^{\circ} \mathrm{N}$ remains relatively distinct also in the deposition for all the simulations (although it seen as a shoulder in the $100 \% \mathrm{Hg}_{(\mathrm{g})}^{0}$ profile). The peak north of $60^{\circ} \mathrm{N}$ is more dependent on emission speciation, supporting the previous finding that the location of $\mathrm{Hg}$ deposition depends on complex interactions between emission location and the time of year which influences both atmospheric trans-

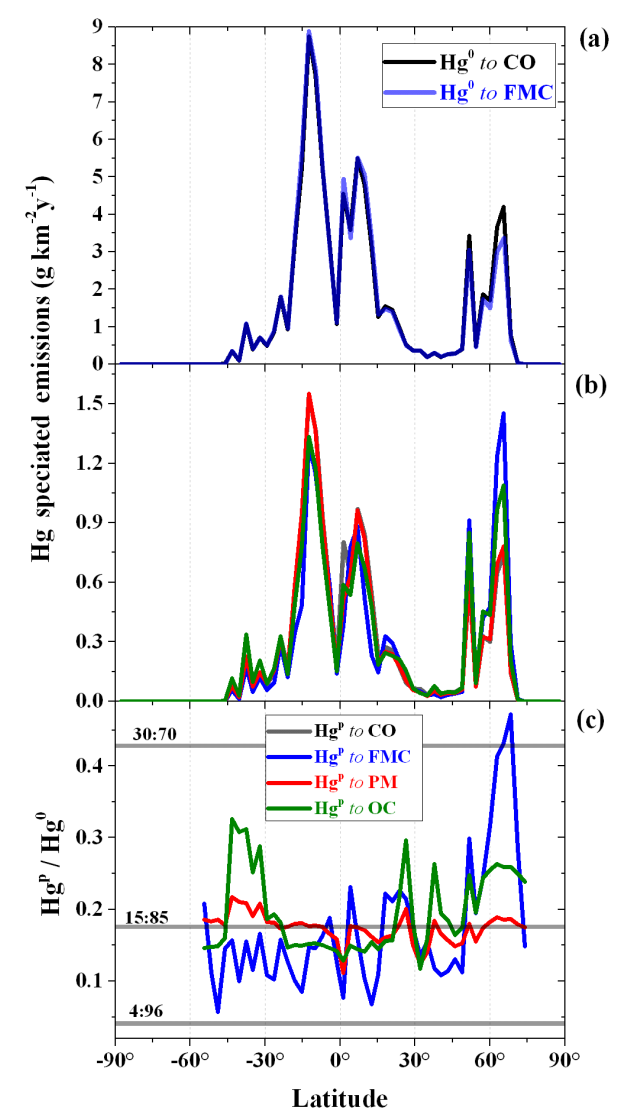

Figure 4. Latitudinal profiles of (a) $\mathrm{Hg}_{(\mathrm{g})}^{0}$ emissions when mapped to $\mathrm{CO}$ and when speciation is determined by FMC; (b) $\mathrm{Hg}^{\mathrm{P}}$ emissions when mapped to $\mathrm{CO}, \mathrm{PM}$ and $\mathrm{OC}$ and when speciation is driven by FMC; and (c) the relevant ratio $\mathrm{Hg}^{\mathrm{P}}: \mathrm{Hg}_{(\mathrm{g})}^{0}$. For both $\mathrm{Hg}_{(\mathrm{g})}^{0}$ and $\mathrm{Hg}^{\mathrm{P}}$ emissions mapped to $\mathrm{CO}$, only the speciation $\left(15: 85 \mathrm{Hg}^{\mathrm{P}}: \mathrm{Hg}_{(\mathrm{g})}^{0}\right)$ is reported for clarity, whereas in (c) all the speciations are reported.

port patterns and oxidant concentration fields (De Simone et al., 2015).

\subsection{Geographical distribution of $\mathrm{Hg}$ deposition}

Due to the uncertainty in the atmospheric oxidation pathway of $\mathrm{Hg}$, simulations were performed using both $\mathrm{O}_{3} / \mathrm{OH}$ and $\mathrm{Br}$ oxidation mechanisms to investigate their impact on $\mathrm{Hg}$ deposition fields. Figure 6a-d compare the geographical distribution of the modelled $\mathrm{Hg}$ deposition field using emission fields with $0 \%$ and of $15 \% \mathrm{Hg}^{\mathrm{P}}$, for each of the oxidation mechanisms. The $\mathrm{O}_{3} / \mathrm{OH}$ mechanism leads to enhanced deposition in the tropics, whereas the $\mathrm{Br}$ mechanism leads to relatively higher deposition over the South Atlantic and Indian oceans. Assuming a fraction of $\mathrm{Hg}^{\mathrm{P}}$ in the emissions subtracts some $\mathrm{Hg}_{(\mathrm{g})}^{0}$ from the global pool, and this fraction is deposited nearer to emission sources in central Africa, South-East Asia, the Amazon and near the wildfires which 


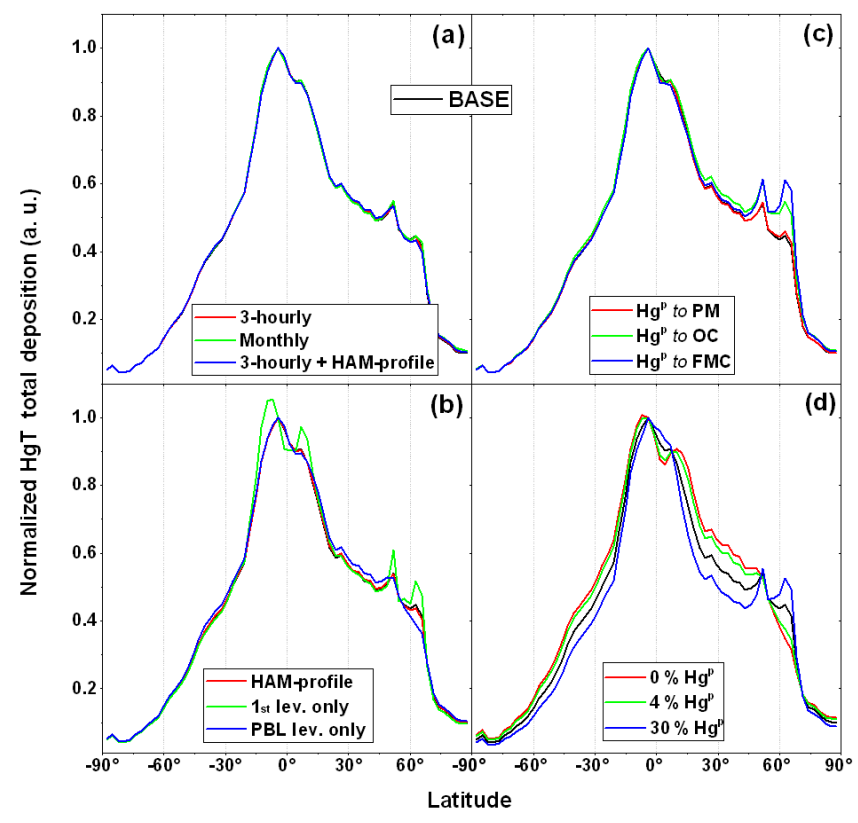

Figure 5. Latitudinal profiles of the normalised $\mathrm{Hg}$ total deposition from the model BASE run, compared with a selection of sensitivity runs, assuming (a-b) different emission time resolution and vertical profile, as well as a combination of both; (c) different $\mathrm{Hg}^{\mathrm{P}}$ emission geographical distributions, as well as different $\mathrm{Hg}_{(\mathrm{g})}^{0}: \mathrm{Hg}^{\mathrm{P}}$ ratios. The normalisation was done by maximum.

occur in North America and in North Asia in the northern hemispheric summer. From Fig. 6, it appears that assuming a fraction of the $\mathrm{BB}$ emissions to be $\mathrm{Hg}^{\mathrm{P}}$ causes the deposition field simulated using the $\mathrm{Br}$ oxidation mechanism to more closely resemble that using the $\mathrm{O}_{3} / \mathrm{OH}$ mechanism. To better understand the combined effect of $\mathrm{Hg}$ speciation and oxidation pathway on the deposition distribution, agreement maps were created to highlight the similarities and differences in the distribution of high-deposition $(\geqslant \mu+1 \sigma$, the average plus 1 standard deviation) model cells in the different simulations as described in De Simone et al. (2014). Figure $7 \mathrm{a}$ and $\mathrm{b}$ show the agreement maps of the deposition for three different $\mathrm{Hg}^{\mathrm{P}}$ fractions using the two oxidation mechanisms. Using the $\mathrm{O}_{3} / \mathrm{OH}$ mechanism, the number of model cells in which the model predicts high deposition in all three emission speciation scenarios is higher than when using the $\mathrm{Br}$ mechanism (631 vs. 248). This is due to the combination of high emissions and high oxidant concentrations in the tropics when using the $\mathrm{O}_{3} / \mathrm{OH}$ mechanism, constraining $\mathrm{Hg}$ deposition to a relatively narrow latitude band. Using the $\mathrm{Br}$ mechanism, $\mathrm{Hg}$ has a greater possibility of being transported to mid- and high latitudes before being oxidised and deposited. In both the oxidation scenarios the higher deposition over the remote areas of North America and North Asia occurs only when the fraction of $\mathrm{Hg}^{\mathrm{P}}$ in the emissions is greater than zero. High local contributions to $\mathrm{Hg}$ deposition from $\mathrm{BB}$ using the $\mathrm{Br}$ mechanism occur more frequently
Table 2. Characteristics of ground-based sites measuring $\mathrm{Hg}^{\mathrm{P}}$.

\begin{tabular}{rrrrr}
\hline Long name & Short name & Lat & Long & Elev. $(\mathrm{m})$ \\
\hline Amsterdam Island & AMD & -37.8 & 77.58 & 70 \\
Cape Hedo & CHE & 26.86 & 128.25 & 60 \\
Longobucco & LON & 39.39 & 16.61 & 1379 \\
Manaus & MAN & -2.89 & -59.97 & 110 \\
Mauna Loa & MAU & 19.54 & -155.58 & 3399 \\
Mt. Changbai & MCH & 42.4 & 128.11 & 741 \\
Mt. Waliguan & MWA & 36.29 & 100.9 & 3816 \\
Rao & RAO & 57.39 & 11.91 & 5 \\
\hline
\end{tabular}

when the fraction of $\mathrm{Hg}^{\mathrm{P}}$ is non-zero (purple in Fig. 7b), unlike the $\mathrm{O}_{3} / \mathrm{OH}$ simulations. Figure 8 contrasts the results from the two oxidation mechanisms with varying percentages of $\mathrm{Hg}^{\mathrm{P}}$ and a simulation in which the $\mathrm{Hg}^{\mathrm{P}}$ fraction was assumed to be $100 \%$, so that it behaves as an inert tracer. The agreement maps show clearly that the similarity in the deposition fields increases with increasing $\mathrm{Hg}^{\mathrm{P}}$ fraction, reflected in the number of cells where all three simulations agree (grey in the figure) and the decrease in the number of cells where only one simulation predicts deposition higher than $\mu+\sigma$ (red, blue and yellow).

\subsection{Constraints from global measurements networks}

The output from the simulations including all emissions (as indicated in Table 1) for the year 2013 were compared to measurement data available from GMOS and other monitoring networks. The sites are the same as those used in Travnikov et al. (2016), the measurements from which have been reviewed Sprovieri et al. (2016a, b). Table 6 summarises a selection of metrics from the comparison for total gaseous mercury (TGM; $\mathrm{Hg}_{(\mathrm{g})}^{0}+\mathrm{Hg}_{(\mathrm{g})}^{0}$ ) and for $\mathrm{Hg}$ in wet deposition. The results are in line with those obtained from previous studies (De Simone et al., 2015, 2016) focusing on a different time period, and they indicate a generally good agreement between measured and simulated TGM, especially for the run with the Br-driven oxidation mechanism. For the $\mathrm{Hg}$ wet deposition fluxes, the results show poorer performance due to the difficulties for coarse-resolution global models to simulate precipitation events correctly (De Simone et al., 2014; Roeckner et al., 2003). Since the different sensitivity runs considering $\mathrm{Hg}^{\mathrm{P}}$ from $\mathrm{BB}$ differ by a only a small perturbation in the speciation of total $\mathrm{Hg}$ emitted from the BASE (or the relevant reference) case, the results are actually indistinguishable from BASE (or the relevant reference) case. Therefore the table reports the comparison only from runs which yield different results. Also, this means that neither wet deposition nor TGM is the most appropriate variable to assess the validity of any of the assumptions concerning $\mathrm{Hg}^{\mathrm{P}}$ emitted during BB. During 2013, within the GMOS and other Hg monitoring initiatives, a number of measurement sites collected samples of atmospheric $\mathrm{Hg}^{\mathrm{P}}$. These stations and their precise locations are reported in the Table 2 . The result of 

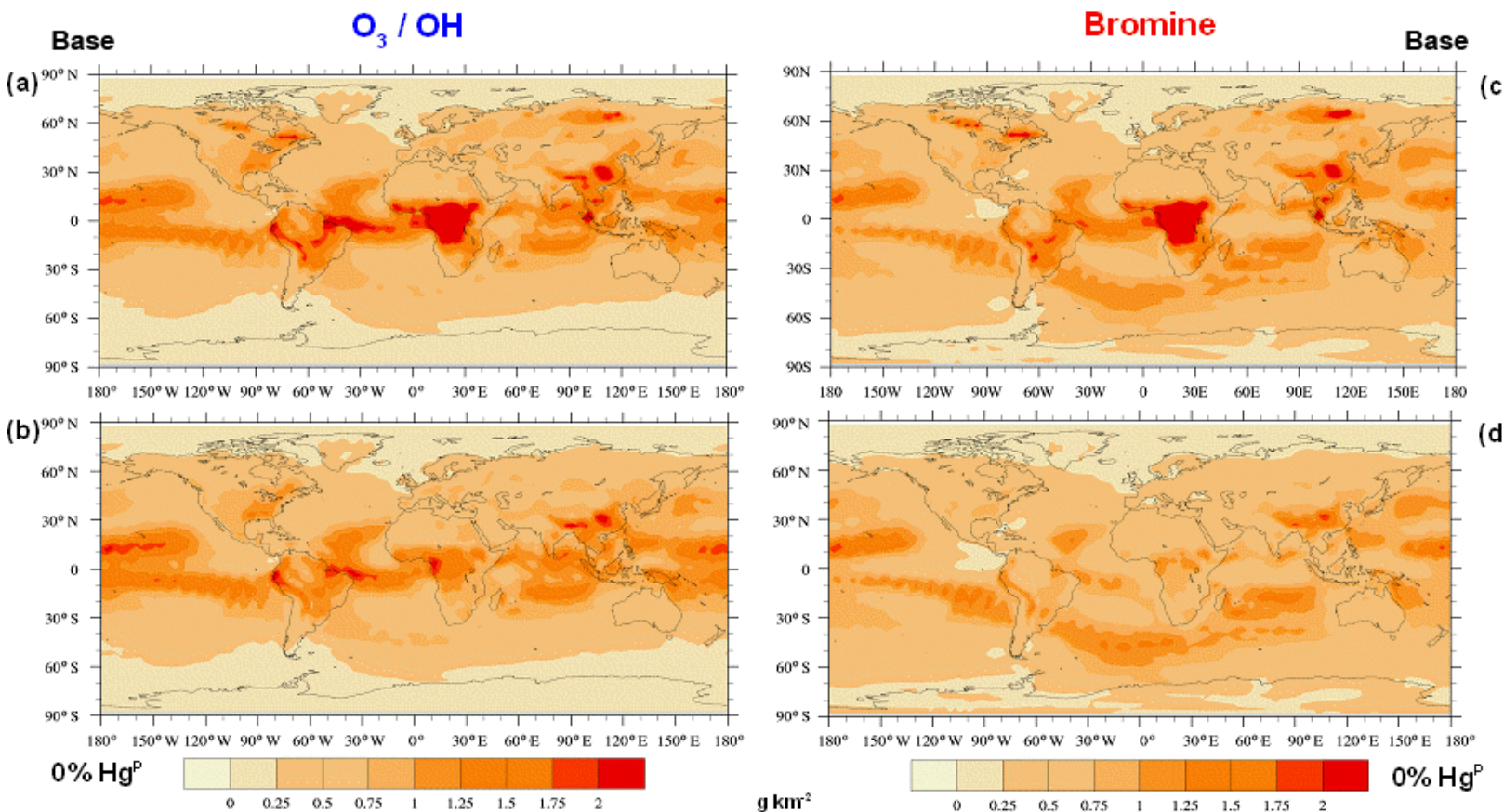

(c)

(d)

Figure 6. Geographical distribution of the $\mathrm{Hg}$ total deposition from model runs including only $\mathrm{BB}$ emission sources and assuming two different $\mathrm{Hg}^{\mathrm{P}}$ emission fractions, $15 \%(\mathbf{a}, \mathbf{c})$ and $0 \%(\mathbf{b}, \mathbf{d})$, for the two oxidation mechanisms considered, $\mathrm{O}_{3} / \mathrm{OH}(\mathbf{a}-\mathbf{b})$ and $\mathrm{Br}(\mathbf{c}-\mathbf{d})$.

(a)
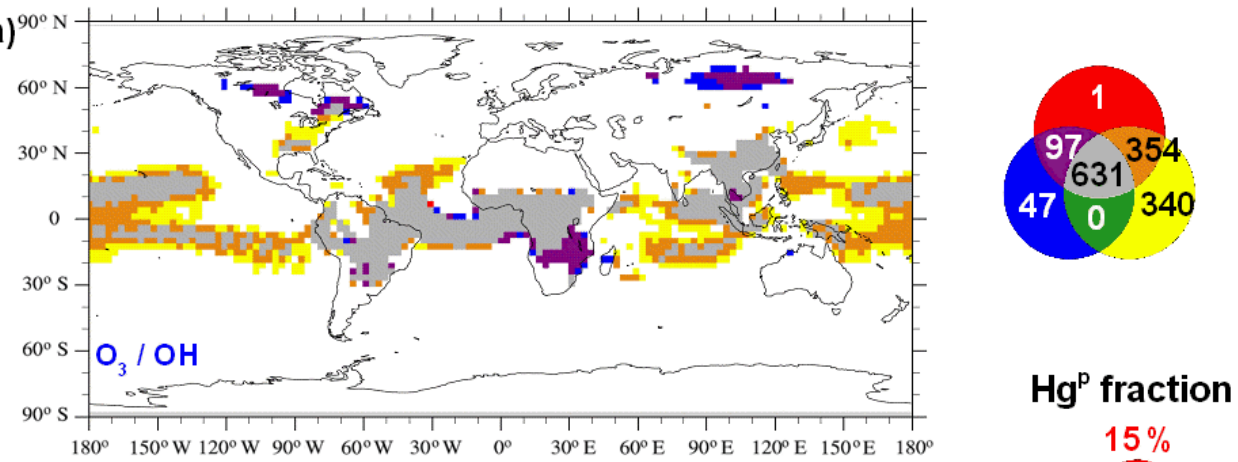

(b)
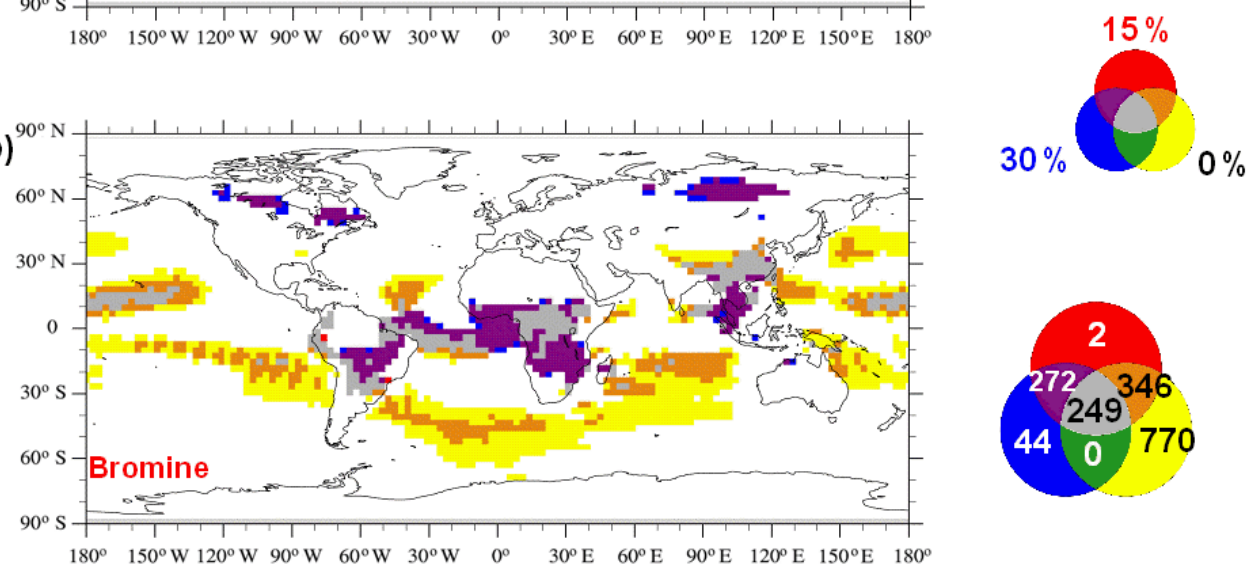

Figure 7. Agreement maps of high $\mathrm{Hg}$ deposition model cells obtained considering only $\mathrm{BB}$ emissions and assuming 0,15 and $30 \%$ to be $\mathrm{Hg}^{\mathrm{P}}$ under both the oxidation mechanisms considered, $\mathrm{O}_{3} / \mathrm{OH}(\mathbf{a})$ and $\mathrm{Br}(\mathbf{b})$. The maps show the areas where deposition is greater than $\mu+\sigma$. 


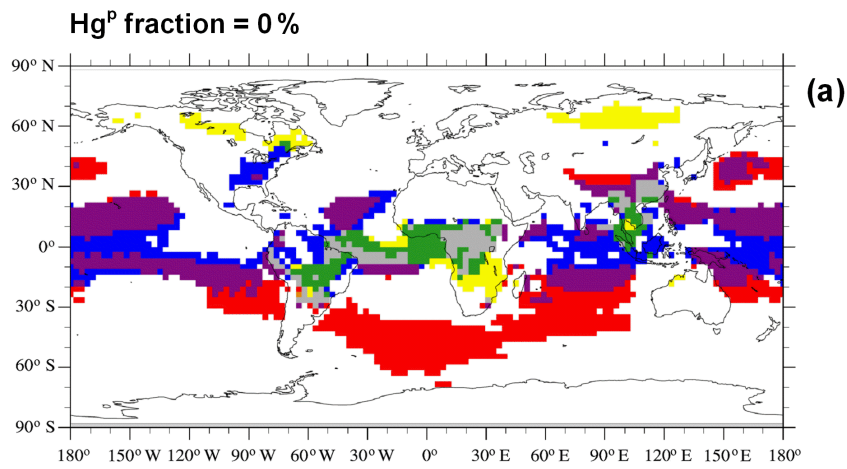

(a)

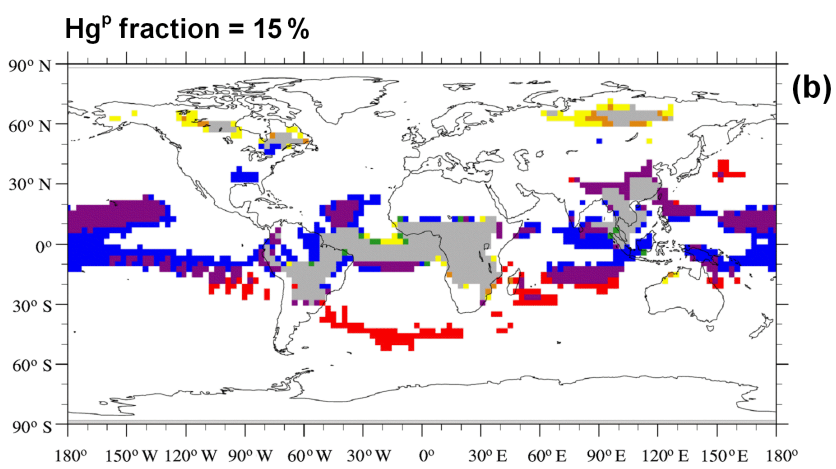

(b)

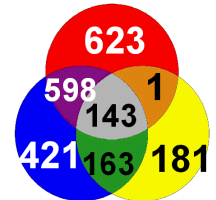

$\mathrm{Hg}^{\mathrm{p}}$ fraction $=30 \%$

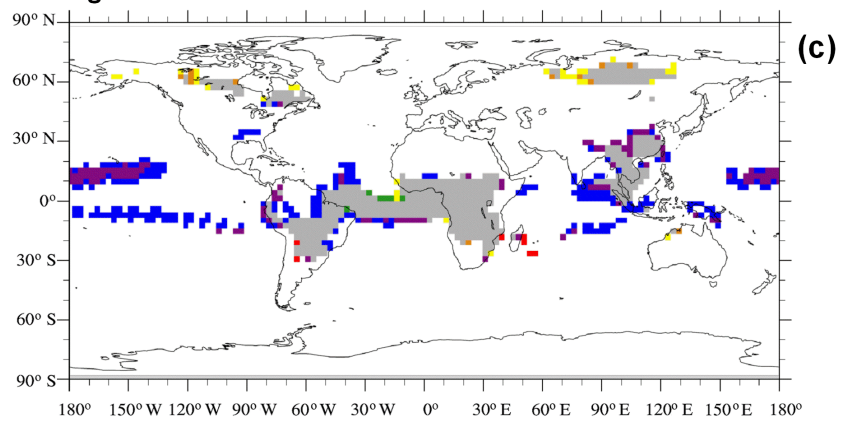

(c)
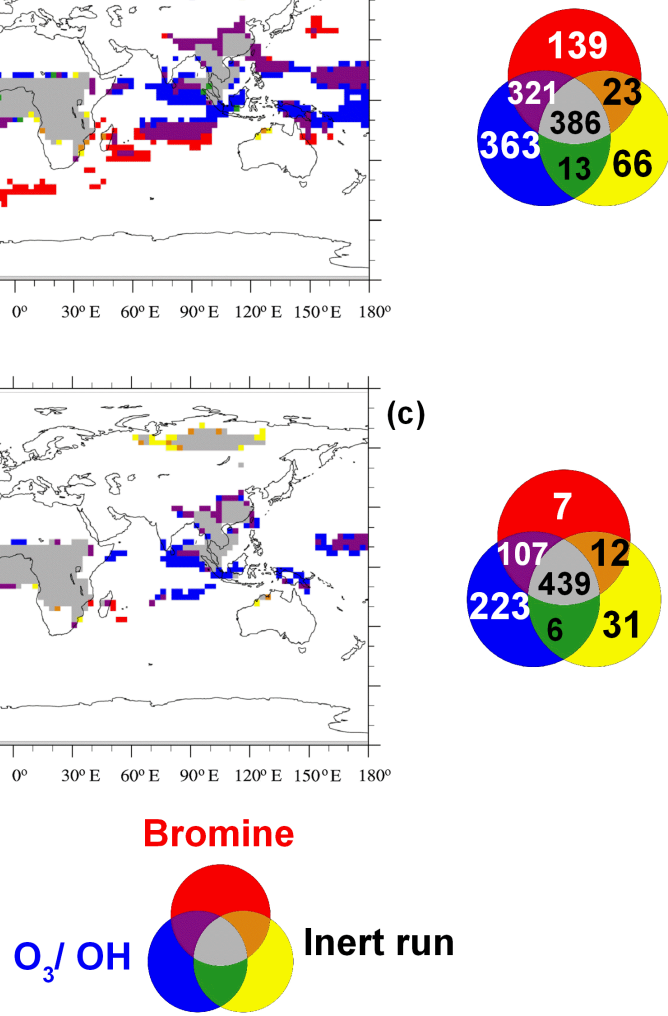

Figure 8. Agreement maps, under three different speciation scenarios, $0 \%$ (a), $15 \%$ (b) and $30 \%$ (c) $\mathrm{Hg}^{\mathrm{P}}$, of high $\mathrm{Hg}$ deposition model cells obtained considering only $\mathrm{BB}$ and using the $\mathrm{O}_{3} / \mathrm{OH}$, the Broxidation mechanisms, and a sensitivity run where all $\mathrm{Hg} \mathrm{BB}$ emissions were considered inert (i.e. all $\mathrm{Hg}^{\mathrm{P}}$ ). The deposition field from for this "inert" run was retained under the three different speciation scenarios. The maps show the areas where deposition is greater than $\mu+\sigma$.

the comparison with the measurements from these sites is summarised in Fig. 9. Figure 9a shows the annually averaged surface concentrations of $\mathrm{Hg}^{\mathrm{P}}$ as simulated by the BASE run for 2013. As is evident, surface $\mathrm{Hg}^{\mathrm{P}}$ hotspots are close to the industrial areas of eastern Europe, India, East Asia and South Africa and to areas characterised by significant BB activity, including Indonesia, central Africa and boreal areas of Canada and Asia.
A first analysis to find those areas where the model run, assuming a fraction $\mathrm{Hg}^{\mathrm{P}}$ from $\mathrm{BB}$ (i.e. BASE), gives results that are statistically distinguishable from the model run assuming $\mathrm{Hg}$ from $\mathrm{BB}$ to be only $\mathrm{Hg}_{(\mathrm{g})}^{0}$ was performed to identify the measurements sites best suited for further analysis.

The geographical distribution of these differences is reported in panel b of Fig. 9. The areas were the anthropogenic input is the greatest differ little between the simulations (based on a Student $t$ test at $95 \%$ level of confidence), as 


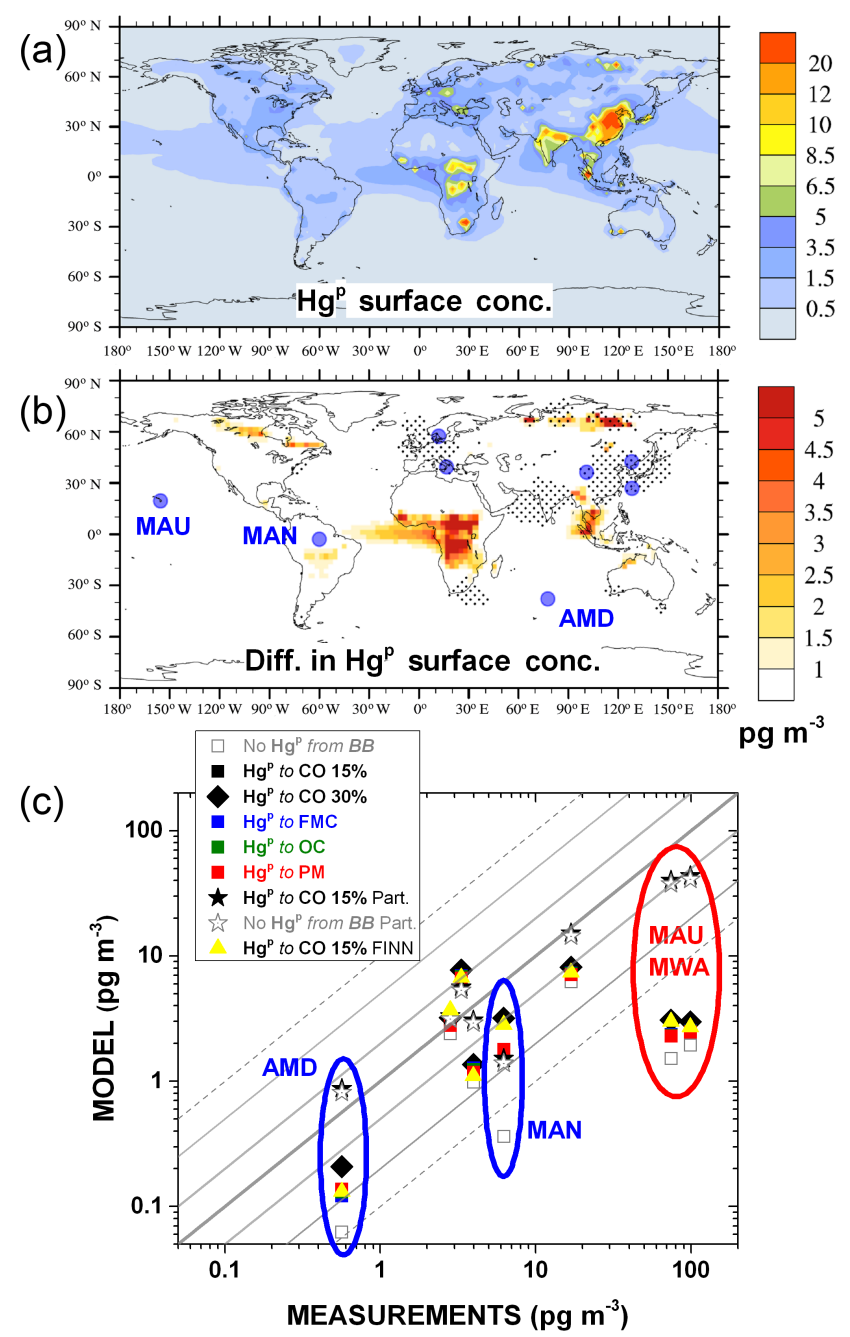

Figure 9. (a) Annual averaged surface $\mathrm{Hg}^{\mathrm{P}}$ concentrations as simulated by BASE run including all emission sources. (b) Differences in annual averaged surface $\mathrm{Hg}^{\mathrm{P}}$ concentrations as simulated by BASE and by $\mathrm{NO} \mathrm{Hg}^{\mathrm{P}}$ runs, both including emissions from all sources. Black dots indicate that differences are not significant based on a Student $t$ test at a $95 \%$ confidence interval. Blue bigger points indicate the locations of measurements sites reported in Table 2. Short names are depicted for sites where the differences between BASE and $\mathrm{NO}_{\mathrm{Hg}} \mathrm{P}$ runs are significant. (c) Scatter plot of annual averaged $\mathrm{Hg}^{\mathrm{P}}$ concentrations measured at sites of Table 2 compared with those obtained by different sensitivity runs. The blue circles in the figure indicate values relative to the sites further investigated at an higher temporal resolution (see Fig. 10), whereas the red circles indicate values relative to high-altitude sites affected by processes other than $\mathrm{BB}$.

indicated by dot points in the panel. Most of the stations, depicted by the blue solid points in the same panel, are within these regions and therefore unsuitable for the analysis. Only three stations are in areas where the model results are significantly different. These, the short names of which are reported in the panel, are Amsterdam Island (AMD), Manaus (MAN) and Mauna Loa (MAU). However, MAU and Mt. Waliguan (MWA) are high-altitude sites and affected by processes other than BB. For both the remaining stations (AMD and MAN), the fraction of $\mathrm{Hg}^{\mathrm{P}}$ that is assumed to be emitted by anthropogenic activities, as estimated by AMAP2010 inventory (AMAP/UNEP, 2013), is not sufficient alone to explain the averaged $\mathrm{Hg}^{\mathrm{P}}$ concentrations collected over the year, as is evident from Fig. 9c. The inclusion of $30 \% \mathrm{Hg}^{\mathrm{P}}$ from $\mathrm{BB}$ emissions at MAN and AMD and also the inclusion of $15 \%$ $\mathrm{Hg}^{\mathrm{P}}$ from $\mathrm{BB}$ as using the FINN inventory at MAN significantly improve the model performances, in terms of the annual average $\mathrm{Hg}^{\mathrm{P}}$ concentrations. The result of the comparison between the $\mathrm{Hg}^{\mathrm{P}}$ concentrations collected at these two stations with the same modelled at the same points by a selection of sensitivity runs at an finer temporal resolution (daily averages) is reported in the two panels of Fig. 10. The same comparisons for all the stations, among with the box and whisker plot of distributions of the $\mathrm{Hg}^{\mathrm{P}}$ concentrations measured and modelled, are reported in Fig. 11. Although the measurement coverage of the year at MAN is sporadic, it is an important station because it is situated in a remote area where the local $\mathrm{Hg}$ emissions are due only to ASGM (only $\mathrm{Hg}_{(\mathrm{g})}^{0}$ ) and BB (Sprovieri et al., 2016b). The consistent reduction of the error between measured and modelled $\mathrm{Hg}^{\mathrm{P}}$ concentrations when considering a fraction of particulate bound $\mathrm{Hg}$ emitted from BB (NRMSE from 48 to $34 \%$ and 27 for $30 \% \mathrm{Hg}^{\mathrm{P}}$ and FINN, respectively) clearly indicates the role of $\mathrm{BB}$ on the observed $\mathrm{Hg}^{\mathrm{P}}$ values. At AMD (Fig. 10b), the inclusion of the fraction of $\mathrm{Hg}^{\mathrm{P}}$ from $\mathrm{BB}$ results only in a slightly better agreement with the measurements (NRMSE from 16 to $14 \%$ ). However, the $\mathrm{Hg}^{\mathrm{P}}$ event matching grows from 25 to $32 \%$, especially in the last part of the year. These $\mathrm{Hg}^{\mathrm{P}}$ events have been associated with BB events in the central Africa in Angot et al. (2014). Peaks was evaluated using the "findpeak" function in MATLAB, available from https: //it.mathworks.com/help/signal/ref/findpeaks.html. To summarise, it seems that the emissions of a fraction $\mathrm{Hg}^{\mathrm{P}}$ from $\mathrm{BB}$ is plausible and supported by the measures of atmospheric $\mathrm{Hg}^{\mathrm{P}}$, at least for the period investigated and for the location of the two remote stations AMD and MAN. However, it has to be noted that the uncertainties related to the precise nature of atmospheric $\mathrm{Hg}^{\mathrm{P}}$ and to the processes it undergoes in the atmosphere could have an appreciable impact on the model results. For example, the assumption of a temperaturedependent gas-particle $\mathrm{Hg}^{\mathrm{II}}$ partitioning proposed by Amos et al. (2012) (i.e. the "Partitioning" and "Partitioning ref" runs) yield overall better model agreement with annually average $\mathrm{Hg}^{\mathrm{P}}$ concentrations (stars in Fig. 9c). However, comparing the modelled daily average time series with measurements results in clearly poorer performance at both the AMD and MAN stations (see Fig. 12b and c). More importantly, this assumption tends to render statistically indistinguishable (Student $t$ test at $95 \%$ level of confidence) the contribution of any eventual $\mathrm{Hg}^{\mathrm{P}}$ from BB, as evident from Fig. 12a. 


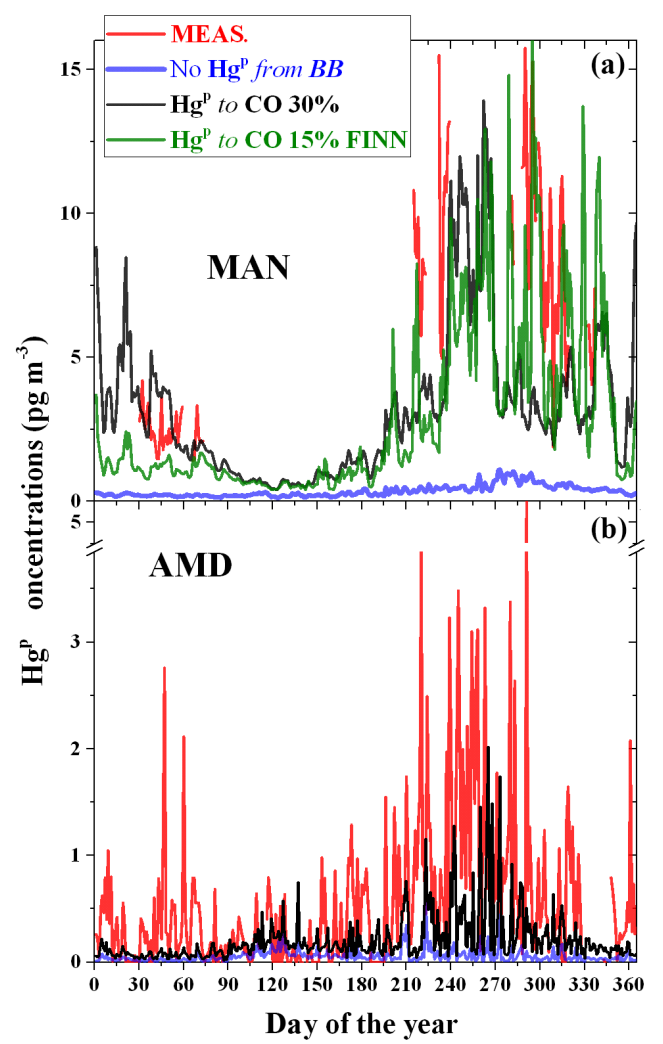

Figure 10. Temporal evolution of daily averaged surface $\mathrm{Hg}^{\mathrm{P}}$ concentrations measured at Manaus (MAN) and Amsterdam Island (AMD) for the entire 2013, compared with a selection of sensitivity runs.

\subsection{Uncertainty and biomass burning versus anthropogenic impact}

Besides the uncertainty related to the atmospheric $\mathrm{Hg}$ oxidation mechanism (Hynes et al., 2009; Subir et al., 2011, 2012; Gustin et al., 2015; Ariya et al., 2015) there are a number of other factors that lead to uncertainty in ascertaining the fate of $\mathrm{Hg}$ released by $\mathrm{BB}$. Some of the model assumptions and parametrisations, in particular emission height, made little difference to the eventual deposition fields in the case where emissions from BB were considered to be $100 \% \mathrm{Hg}_{(\mathrm{g})}^{0}$ (De Simone et al., 2015). Other sensitivity studies of the speciation of anthropogenic emissions reveal that varying the fractions of $\mathrm{Hg}_{(\mathrm{g})}^{\mathrm{II}}$ and $\mathrm{Hg}^{\mathrm{P}}$ can result in quite different $\mathrm{Hg}$ deposition patterns due to their shorter residence time compared to $\mathrm{Hg}_{(\mathrm{g})}^{0}$ (De Simone et al., 2016; Bieser et al., 2014).

However, the choice of the two main vertical profile of the $\mathrm{BB}$ emissions used in this study, also when combined with the temporal resolution of the emissions, actually has little influence on the final $\mathrm{Hg}$ deposition fields. Emitting all of the $\mathrm{Hg}$ in a single model layer does have an impact. However, these cases are a little speculative, and therefore not included in the final analysis. The factor which has the greatest influence on the $\mathrm{Hg}$ deposition pattern is the choice of emis-

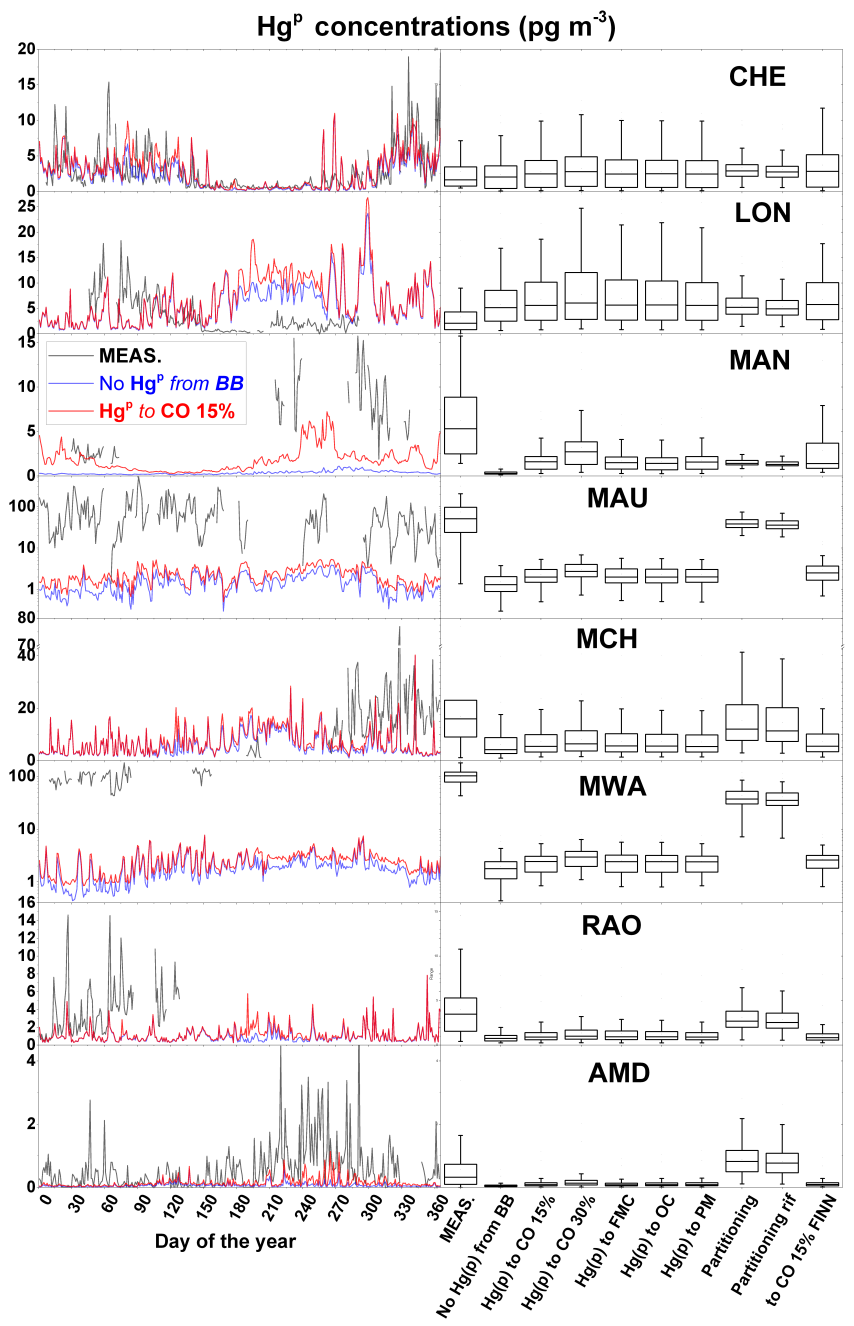

Figure 11. Left column: temporal evolution of the daily averaged surface $\mathrm{Hg}^{\mathrm{P}}$ concentrations measured at all sites from Table 2 for the entire 2013, compared with the modelled values as simulated by $\mathrm{BASE}$ and by $\mathrm{NO} \mathrm{Hg}^{\mathrm{P}}$ runs, including emissions from all sources. Right column: box plots of the distribution of the of the daily averaged surface $\mathrm{Hg}^{\mathrm{P}}$ concentrations, for the entire 2013, as measured and simulated by the different sensitivity runs. Note the logarithmic for both MAU and MWA subplot.

sion inventory, whereas for a given inventory the most important factors are the fraction of $\mathrm{Hg}^{\mathrm{P}}$ and the oxidation mechanism, although as seen in Sect. 3.3 the impact of the oxidation mechanism decreases with increasing $\mathrm{Hg}^{\mathrm{P}}$ fraction. The method of calculating the $\mathrm{Hg}^{\mathrm{P}}$ fraction has a limited impact on deposition on a global scale, with $66 \%$ of $\mathrm{Hg}$ deposited over the oceans, but the regional impact does change. Using FMC to determine the $\mathrm{Hg}^{\mathrm{P}}$ fraction increases deposition to the Arctic by 16 and $13 \%\left(\mathrm{O}_{3} / \mathrm{OH}\right.$ and $\left.\mathrm{Br}\right)$ and to the Southern Ocean by 30 and $25 \%\left(\mathrm{O}_{3} / \mathrm{OH}\right.$ and $\left.\mathrm{Br}\right)$; see Table 4. Apart from the polar oceans the oceanic basins, most influenced by the fraction of $\mathrm{Hg}^{\mathrm{P}}$ in the $\mathrm{BB}$ emissions are the North and South Pacific and the Indian ocean. The to- 

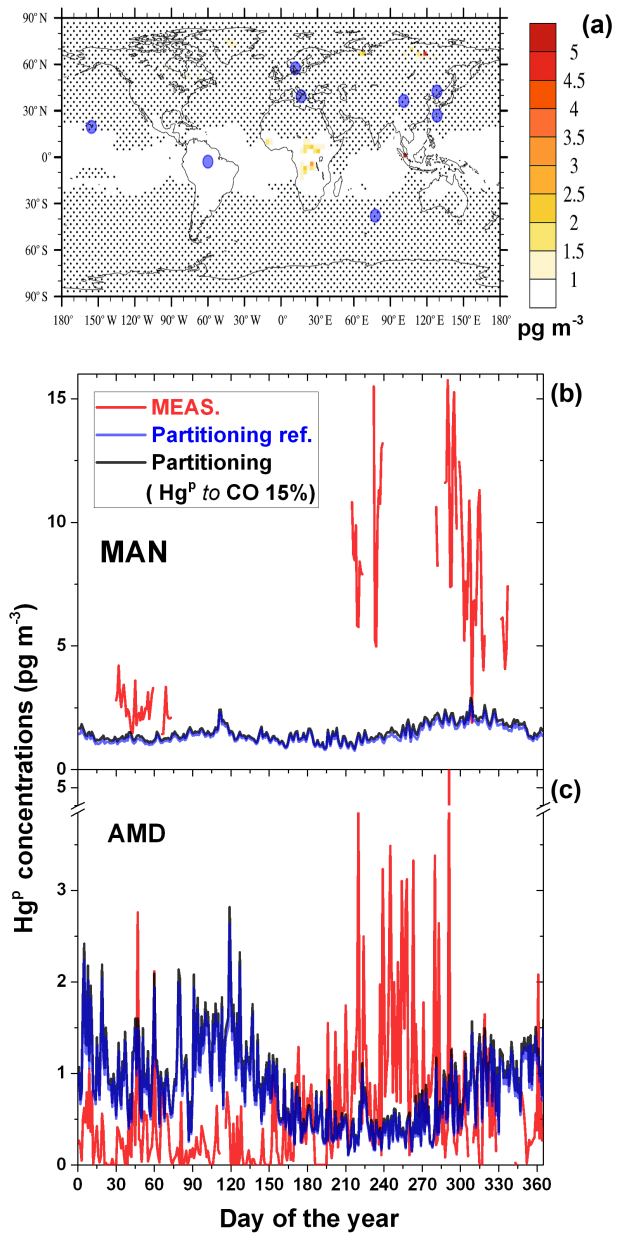

Figure 12. (a) Differences in annual averaged surface $\mathrm{Hg}^{\mathrm{P}}$ concentrations as simulated by Partitioning and by Partitioning ref. runs, both including emissions from all sources and the temperaturedependent $\mathrm{Hg}^{\mathrm{II}}$ gas-particle partitioning as implemented in Amos et al. (2012). Black dots indicate that differences are not significant based on a Student $t$ test at a $95 \%$ confidence interval. Bigger blue points indicate the locations of measurements sites reported in Table 2. Temporal evolution of daily averaged surface $\mathrm{Hg}^{\mathrm{P}}$ concentrations are measured at Manaus (MAN) and Amsterdam Island (AMD) for the entire 2013, compared with the modelled values from the same sensitivity runs.

tal deposition to individual basins from the limiting 0 and $30 \% \mathrm{Hg}^{\mathrm{P}}$ cases is included in Table 4. The horizontal pattern correlation method (Santer et al., 1995, 1996) and the non-parametric Kolmogorov-Smirnov two-sample test were used to assess the differences in the deposition fields obtained from the simulations summarised in Table 1, as in De Simone et al. (2015). The results of the comparison of the simulations with the BASE run are presented in Table 3. The results of the Kolmogorov-Smirnov two-sample test were exploited to construct an inspected ensemble, following the approach of Solazzo and Galmarini (2015) and previously employed in De Simone et al. (2015). The ensemble includes
Table 3. Horizontal pattern correlation $(R)$ and probabilities that the $\mathrm{Hg}$ deposition fields of the different runs belong to the same distribution as the BASE run $\left(P_{\mathrm{KS}}\right)$. The checks in the ensemble column indicate the inclusion of the respective run in the ensemble in Fig. 13.

\begin{tabular}{llrrr}
\hline & Sim. & $R$ & $P_{\text {KS }}$ & Ensemble \\
\hline Time resolution & 3-hourly & 1 & 1 & \\
and & Monthly & 1 & 0.99 & \\
vertical profile & HAM-Profile & 1 & 1 & \\
& 3 h + HAM-Profile & 1 & 1 & \\
\hline $\mathrm{Hg}^{\mathrm{P}}$ mapping & $\mathrm{Hg}^{\mathrm{P}}$ to PM & 1 & 1 & \\
& $\mathrm{Hg}^{\mathrm{P}}$ to OC & 1 & 0.42 & $\checkmark$ \\
& $\mathrm{Hg}^{\mathrm{P}}$ to FMC & 0.99 & 0.45 & $\checkmark$ \\
\hline $\mathrm{Hg}^{\mathrm{P}}$ fraction & $\mathrm{NO} \mathrm{Hg}$ & 0.94 & 0.38 & $\checkmark$ \\
& $4 \%$ Hg & 0.97 & 0.72 & $\checkmark$ \\
& $30 \%$ Hg & 0.97 & 0.5 & $\checkmark$ \\
\hline Inventory & $\mathrm{GFAS}$ & 0.98 & 0 & $\checkmark$ \\
& $\mathrm{FINN}$ & 0.96 & 0 & $\checkmark$ \\
\hline Oxidation mech. & $\mathrm{Br}$ & 0.96 & 0 & $\checkmark$ \\
and & $\mathrm{Br} \mathrm{No} \mathrm{Hg}{ }^{\mathrm{P}}$ & 0.81 & 0 & $\checkmark$ \\
combination & $\mathrm{Br} 30 \% \mathrm{Hg}$ & 0.91 & 0 & $\checkmark$ \\
& $\mathrm{Br} \mathrm{Hg}{ }^{\mathrm{P}}$ to OC & 0.95 & 0 & $\checkmark$ \\
& $\mathrm{Br} \mathrm{Hg}{ }^{\mathrm{P}}$ to FMC & 0.94 & 0 & $\checkmark$ \\
& $\mathrm{GFAS} \mathrm{Br}$ & 0.94 & 0 & $\checkmark$ \\
& $\mathrm{FINN} \mathrm{Br}$ & 0.92 & 0 & $\checkmark$ \\
\hline
\end{tabular}

only those simulations with realistic assumptions and deposition fields with little or no probability of belonging to the same distribution. Hg deposition from the resulting ensemble is shown in Fig. 13a. The figure shows how the inclusion of $\mathrm{Hg}^{\mathrm{P}}$ in the $\mathrm{BB}$ emissions causes greater deposition near the hotspots of central Africa, Brazil, South-East Asia, North America and North Asia. Nonetheless approximately $70 \%$ of $\mathrm{Hg}$ deposition occurs over the oceans, with the Tropical Atlantic, Tropical Pacific and Indian oceans most impacted (see Table 5). Figure 13b compares the BB ensemble results with an ensemble constructed using only anthropogenic emissions, using the EDGAR (Muntean et al., 2014), AMAP2010 (AMAP/UNEP, 2013) and STREETS (Corbitt et al., 2011) inventories (considering both oxidation mechanisms; see Table 1). It can be seen that the contribution of BB to $\mathrm{Hg}$ deposition is close to or greater than that from anthropogenic activities in the areas near the locations of wildfires, central Africa, the Amazon, part of the Southern Atlantic and North Asia. The contribution to $\mathrm{Hg}$ deposition from BB relative to anthropogenic emissions is greater than $25 \%$ everywhere in the Southern Hemisphere and exceeds $30 \%$ in the South Pacific and South Atlantic (Table 5). As anthropogenic $\mathrm{Hg}$ emissions decline the relative impact of $\mathrm{BB} \mathrm{Hg}$ will rise, as shown in Fig. 14, where the $\mathrm{Hg}$ deposition due to $\mathrm{BB}$ is compared with $\mathrm{Hg}$ deposition from anthropogenic sources in three different emission scenarios for 2035 (see Pacyna et al., 2016, for details of the emission scenarios). 
Table 4. Hg deposition $(\mathrm{Mg})$ coming from BB to the oceans as obtained by the different runs for the 2013. The last two columns reports the percentage of the total $\mathrm{Hg}$ that deposits over sea and land.

\begin{tabular}{|c|c|c|c|c|c|c|c|c|c|c|}
\hline \multirow[t]{2}{*}{ Run } & \multicolumn{8}{|c|}{ Total deposition/Mg } & \multicolumn{2}{|c|}{$\%$} \\
\hline & N. Atlantic & S. Atlantic & N. Pacific & S. Pacific & Indian Ocean & Med. Sea & Arctic & S. Ocean & Sea & Land \\
\hline BASE & 31.7 & 32.5 & 75.3 & 67.4 & 45.9 & 1.1 & 5.0 & 2.3 & 66 & 34 \\
\hline $\mathrm{NO} \mathrm{Hg}{ }^{\mathrm{P}}$ & 32.1 & 32.4 & 82.0 & 74.4 & 48.9 & 1.2 & 4.7 & 2.6 & 71 & 29 \\
\hline $30 \% \mathrm{Hg}^{\mathrm{P}}$ & 31.3 & 32.5 & 69.3 & 61.0 & 43.2 & 1.0 & 5.2 & 2.0 & 62 & 38 \\
\hline $\mathrm{Hg}^{\mathrm{P}}$ to $\mathrm{FMC}$ & 31.4 & 32.1 & 74.3 & 66.6 & 44.7 & 1.1 & 5.8 & 2.3 & 66 & 34 \\
\hline $\mathrm{Br}$ No $\mathrm{Hg}^{\mathrm{P}}$ & 26.6 & 39.4 & 75.8 & 83.0 & 55.3 & 1.1 & 3.7 & 7.6 & 74 & 26 \\
\hline $\mathrm{Br} 30 \% \mathrm{Hg}^{\mathrm{P}}$ & 28.0 & 36.4 & 61.7 & 61.1 & 44.9 & 0.9 & 4.8 & 4.6 & 62 & 38 \\
\hline $\mathrm{Br} \mathrm{Hg}^{\mathrm{P}}$ to $\mathrm{FMC}$ & 27.3 & 36.8 & 66.6 & 68.8 & 47.1 & 1.0 & 5.6 & 5.8 & 66 & 34 \\
\hline
\end{tabular}

Table 5. Mercury deposition (Mg) to the oceans for 2013 from BB and comparison (ratio) with deposition from anthropogenic activities for both oxidation mechanisms.

\begin{tabular}{lrrrrrrrr}
\hline $\mathrm{O}_{3} / \mathrm{OH}$ & N. Atlantic & S. Atlantic & N. Pacific & S. Pacific & Indian Ocean & Med. Sea & Arctic & S. Ocean \\
\hline Only BB & 29.8 & 29.9 & 72.1 & 63.0 & 43.0 & 1.1 & 4.7 & 2.1 \\
Only anthropogenic & 144.0 & 80.0 & 417.7 & 206.7 & 151.3 & 10.0 & 34.3 & 11.0 \\
Ratio & 0.21 & 0.37 & 0.17 & 0.31 & 0.28 & 0.11 & 0.14 & 0.19 \\
\hline $\mathrm{Br}$ & N. Atlantic & S. Atlantic & N. Pacific & S. Pacific & Indian Ocean & Med. Sea & Arctic & S. Ocean \\
\hline Only BB & 25.7 & 34.7 & 65.1 & 66.2 & 46.2 & 0.9 & 4.2 & 5.1 \\
Only anthropogenic & 153 & 85.33 & 457.3 & 188.3 & 140 & 12.33 & 34 & 27.3 \\
Ratio & 0.17 & 0.41 & 0.14 & 0.35 & 0.33 & 0.08 & 0.12 & 0.19 \\
\hline
\end{tabular}

\section{Conclusions}

That a fraction of $\mathrm{Hg}^{\mathrm{P}}$ is present in $\mathrm{BB} \mathrm{Hg}$ emissions has been confirmed by several field measurements (Obrist et al., 2007; Finley et al., 2009), and this fact has been suggested as an explanation of high $\mathrm{Hg}^{\mathrm{P}}$ observations at a remote site (Angot et al., 2014), but this is the first time it has been included in a model study to assess its effects on a global scale. A previous modelling study assuming emissions from BB to be $100 \% \mathrm{Hg}_{(\mathrm{g})}^{0}$ (De Simone et al., 2015) suggested that as much as $75 \%$ of the $\mathrm{Hg}$ emitted by $\mathrm{BB}$ was deposited to ocean basins, with global implications for food webs and human health. Including a fraction of $\mathrm{Hg}^{\mathrm{P}}$ in the $\mathrm{BB} \mathrm{Hg}$ emissions has an impact on the geographical distribution of the deposition fluxes for the year analysed, reducing input to the global oceans and some high-latitude regions, while enhancing potentially negative effects on ecosystems close to areas where significant $\mathrm{BB}$ occurs. The presence of $\mathrm{Hg}^{\mathrm{P}}$ in the emissions decreases the differences seen in $\mathrm{Hg}$ deposition patterns produced by employing different oxidation mechanisms. In the remote areas of North Asia and North America, BB has a strong local impact if the $\mathrm{Hg}^{\mathrm{P}}$ fraction is non-zero. This latter result is independent of the atmospheric oxidation pathway. In simulations with $30 \% \mathrm{Hg}^{\mathrm{P}}$ in the $\mathrm{BB}$ emissions, deposition over the Arctic increases by $11 \%$ with respect to $0 \% \mathrm{Hg}^{\mathrm{P}}$ (30\% in the $\mathrm{Br}$ simulations) and by $16 \%$ when the $\mathrm{Hg}^{\mathrm{P}}$ fraction is determined by FMC (37\% in the $\mathrm{Br}$ simu- lation). The fraction of $\mathrm{Hg}^{\mathrm{P}}$ released from $\mathrm{BB}$ while having an impact on the land-sea distribution of global $\mathrm{Hg}$ deposition, has a more significant impact in particular regions including the polar regions, the South Atlantic and Pacific and Indian oceans. These results apply for the investigated year (2013) and may differ for other years due to the complex interaction of the numerous factors determining the final fate of $\mathrm{Hg}$. However, few alternatives of analysis period exist due the limited time coverage of global measurement network(s). Indeed the year selected for the analysis allowed for the hypotheses tested in this study to be supported by observations at a number of sites from GMOS, which has extended the observational network in the tropics and the Southern Hemisphere (Sprovieri et al., 2016a, b). The eventual emissions of a fraction of $\mathrm{Hg}^{\mathrm{P}}$ from $\mathrm{BB}$ cannot be evaluated by comparison with observed gaseous atmospheric $\mathrm{Hg}$ concentrations or $\mathrm{Hg}$ in wet precipitation samples due to the very small impact of $\mathrm{Hg}^{\mathrm{P}}$ from $\mathrm{BB}$ on both the atmospheric burden and wet deposition relative to all other emissions sources $(\approx 1-2 \%)$. Conversely, its contribution to atmospheric $\mathrm{Hg}^{\mathrm{P}}$ is comparable to that of anthropogenic activities and therefore may be investigated. The inclusion in the model run of a fraction of $\mathrm{Hg}^{\mathrm{P}}$ from $\mathrm{BB}$ contributes to better model performances at two remote sites, Manaus and Amsterdam Island. However results are not definitive due to the large uncertainty related to $\mathrm{Hg}^{\mathrm{P}}$ emissions and transformation processes. Further modelling and more measurement sites, particularly in remote ar- 
Table 6. Comparison of the results of BASE and $\mathrm{Br}$ simulations including all emissions sources with observations from measurement networks for 2013 .

\begin{tabular}{lrr|rr|rr|rr}
\hline & \multicolumn{3}{c|}{ Total gaseous mercury } & \multicolumn{3}{c}{ Wet deposition } \\
\cline { 2 - 9 } & \multicolumn{2}{c}{ Regression } & \multicolumn{2}{c|}{ Stats } & \multicolumn{2}{c}{ Regression } & \multicolumn{2}{c}{ Stats } \\
& Intercept & Slope & $r$ & NRMSE \% & Intercept & Slope & $r$ & NRMSE \% \\
\hline BASE & 0.36 & 0.62 & 0.72 & 10.54 & 5.84 & 0.04 & 0.12 & 6.89 \\
Partitioning & 0.34 & 0.7 & 0.73 & 11.9 & 3.71 & 0.03 & 0.14 & 4.76 \\
Br & -0.08 & 0.96 & 0.74 & 15.68 & 7.1 & 0.08 & 0.18 & 9.12 \\
\hline
\end{tabular}
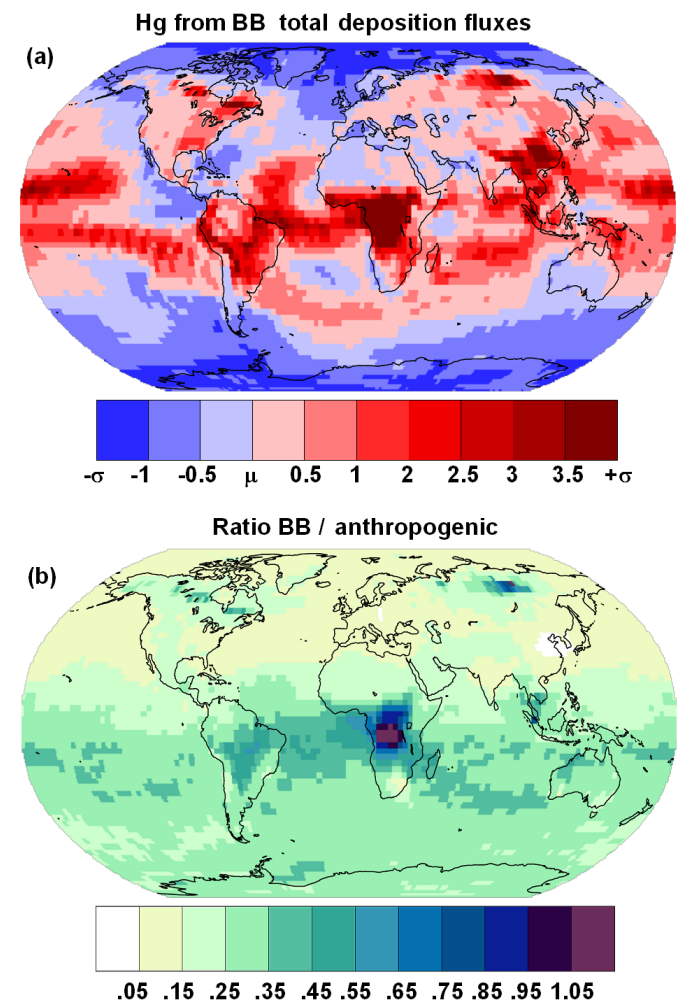

Figure 13. Geographical distribution of the total $\mathrm{Hg}$ deposition from BB emissions obtained from an ensemble of simulations for the year 2013 (a) in terms of the average $(\mu)$ and standard deviation $\sigma$ of the ensemble. The comparison of the BB simulation with an ensemble of runs including only anthropogenic emissions (De Simone et al., 2016) shows (b) the geographic distribution of the fraction of the $\mathrm{BB}$ contribution to the $\mathrm{Hg}$ deposition from the anthropogenic sources.

eas, would help reduce some of the uncertainties associated with $\mathrm{Hg}$ emissions from $\mathrm{BB}$ and constrain these processes. Biomass burning has and will continue to play a significant role in the cycling of legacy $\mathrm{Hg}$, and its relative importance is likely to increase as anthropogenic emissions are reduced and global temperatures rise.

\section{Ratio BB / anthropogenic (x100)}

(a)

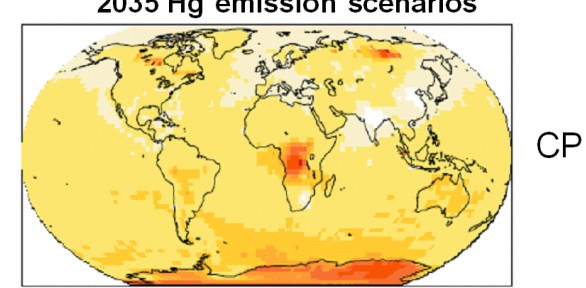

(b)
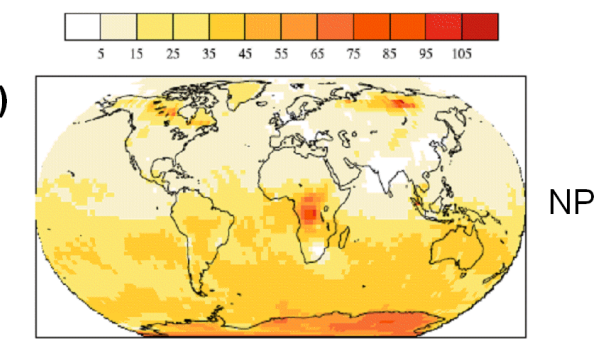

c)
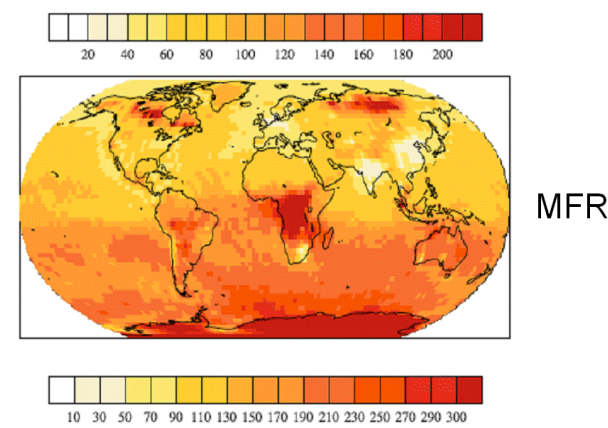

Figure 14. Ratio of the $\mathrm{Hg}$ deposition due to biomass burning with respect to $\mathrm{Hg}$ deposition due to anthropogenic emissions for three anthropogenic emissions scenarios for 2035: (a) current policy (CP), (b) new policy (NP) and (c) maximum feasible reduction (MFR).

\section{Data availability}

Mercury data discussed in this paper are reported within the GMOS central database and are available upon request at http://sdi.iia.cnr.it/geoint/publicpage/GMOS/gmos_ historical.zul. 


\section{Appendix A: How Hg emission fields are calculated}

\section{A1 Mapping to CO}

When mapped to $\mathrm{CO}$, the emissions of $\mathrm{Hg}_{(\mathrm{g})}^{0}$ were calculated from those of $\mathrm{CO}$ using a global averaged ER $\left(1.96 \times 10^{-7}\right)$. These were unchanged in the run assuming $\mathrm{Hg}$ emissions from $\mathrm{BB}$ to be $100 \% \mathrm{Hg}_{(\mathrm{g})}^{0}$ and divided between $\mathrm{Hg}^{\mathrm{P}}$ and $\mathrm{Hg}_{\text {(g) }}^{0}$ species, with ratios $4: 96,15: 85$ and $30: 70$, in mass, in the runs considering the respective constant fractions of $\mathrm{Hg}^{\mathrm{P}}$. Consequently, the geographical and temporal distributions of $\mathrm{Hg}_{(\mathrm{g})}^{0}$ and $\mathrm{Hg}^{\mathrm{P}} \mathrm{BB}$ emissions follow those of $\mathrm{CO}$. For all cases, the GFEDv4 inventory was used, except for those sensitivity runs performed to test the impact of different inventories, FINNv1.5 and GFAS1.4.

\section{A2 Mapping to OC}

When mapped to OC, geographical and temporal distributions of $\mathrm{Hg}_{(\mathrm{g})}^{0} \mathrm{BB}$ emissions, as well as the total $\mathrm{Hg}$ emitted, were calculated as described in Appendix A1. The fractioning of $\mathrm{Hg}$ emissions, in mass, between $\mathrm{Hg}^{\mathrm{P}}$ and $\mathrm{Hg}_{(\mathrm{g})}^{0}$ species was assumed to be in the ratio $15: 85$. The $\mathrm{Hg}^{\mathrm{P}}$ emissions so calculated were then geographically and temporally mapped to those of OC from the GFEDv4 inventory.

\section{A3 Mapping to PM}

This mapping method is similar to the one described in Appendix A2, except for the fact the $\mathrm{Hg}^{\mathrm{P}}$ temporal and geographical distributions follow those of PM from the GFEDv4 inventory.

\section{A4 Emissions speciation determination by FMC}

When using this procedure for determining the BB emission speciation between $\mathrm{Hg}_{(\mathrm{g})}^{0}$ and $\mathrm{Hg}^{\mathrm{P}}$, the geographical and temporal distributions of $\mathrm{Hg}_{(\mathrm{g})}^{0}$ and $\mathrm{Hg}^{\mathrm{P}} \mathrm{BB}$ emissions and the total $\mathrm{Hg}$ emitted were calculated in the same way as described in Appendix A1. The main difference is in that the fractioning of $\mathrm{Hg}$ emissions, in mass, between $\mathrm{Hg}_{(\mathrm{g})}^{0}$ and $\mathrm{Hg}^{\mathrm{P}}$ species were calculated dynamically using the piece wise linear relationship between fuel moisture content empirically determined by relative figure in Obrist et al. (2007). As a proxy for FMC, we used the monthly averaged vegetation water content derived from passive microwave remote sensing data (Advanced Microwave Scanning Radiometer 2 (ASMR2)), and employing the Land Parameter Retrieval Model (LPRM) available at http://gcmd.nasa.gov/search/ Metadata.do?Entry=C1235316240-GES_DISC\#metadata. 
Competing interests. The authors declare that they have no conflict of interest.

Disclaimer. The US Environmental Protection Agency (EPA) through its Office of Research and Development participated in this research. The views expressed in this paper are those of the authors and do not necessarily reflect the views or policies of EPA. It has been subjected to EPA Agency review and approved for publication. Mention of trade names or commercial products does not constitute endorsement or recommendation for use.

Acknowledgements. We are grateful to Sebastian Rast and colleagues at the Max Planck Institute for Meteorology in Hamburg, Germany, for the distribution of their software ECHAM5 and for providing the access to the processed ERA-INTERIM data. We are grateful to Xin Yang for providing the $\mathrm{Br} / \mathrm{BrO}$ fields from p-Tomcat. The research was performed in the framework of the EU project GMOS (FP7-265113). The authors would also like to thank the referees whose helpful suggestions and comments contributed much to improving the original manuscript.

Edited by: R. Ebinghaus

Reviewed by: M. Cohen, T. Dvonch, and two anonymous referees

\section{References}

Akagi, S. K., Yokelson, R. J., Wiedinmyer, C., Alvarado, M. J., Reid, J. S., Karl, T., Crounse, J. D., and Wennberg, P. O.: Emission factors for open and domestic biomass burning for use in atmospheric models, Atmos. Chem. Phys., 11, 4039-4072, doi:10.5194/acp-11-4039-2011, 2011.

AMAP/UNEP: Technical Background Report for the Global Mercury Assessment 2013, Tech. rep., Arctic Monitoring and Assessment Programme, Oslo, Norway/UNEP ChemicalsBranch, Geneva, Switzerland, available at: http://www.amap.no/documents/doc/ technical-background-report-for-the-global-mercury-assessment848 (last access: 1 February 2017), 2013.

Amos, H. M., Jacob, D. J., Holmes, C. D., Fisher, J. A., Wang, Q., Yantosca, R. M., Corbitt, E. S., Galarneau, E., Rutter, A. P., Gustin, M. S., Steffen, A., Schauer, J. J., Graydon, J. A., Louis, V. L. St., Talbot, R. W., Edgerton, E. S., Zhang, Y., and Sunderland, E. M.: Gas-particle partitioning of atmospheric $\mathrm{Hg}$ (II) and its effect on global mercury deposition, Atmos. Chem. Phys., 12, 591-603, doi:10.5194/acp-12-591-2012, 2012.

Andela, N., Kaiser, J., Heil, A., van Leeuwen, T., van der Werf, G., Wooster, M., Remy, S., and Schultz, M.: Assessment of the Global Fire Assimilation System (GFASv1), MACC-II (Monitoring Atmospheric Composition and Climate) project, available at: http://juser.fz-juelich.de/record/186645 (last access: 5 May 2016), 2013.

Andersson, M. E., Sommar, J., Gårdfeldt, K., and Jutterström, S.: Air - sea exchange of volatile mercury in the North Atlantic Ocean, Mar. Chem., 125, 1-7, 2011.
Angot, H., Barret, M., Magand, O., Ramonet, M., and Dommergue, A.: A 2-year record of atmospheric mercury species at a background Southern Hemisphere station on Amsterdam Island, Atmos. Chem. Phys., 14, 11461-11473, doi:10.5194/acp14-11461-2014, 2014.

Ariya, P. A., Amyot, M., Dastoor, A., Deeds, D., Feinberg, A., Kos, G., Poulain, A., Ryjkov, A., Semeniuk, K., Subir, M., and Toyota, K.: Mercury Physicochemical and Biogeochemical Transformation in the Atmosphere and at Atmospheric Interfaces: A Review and Future Directions, Chem. Rev., 115, 3760-3802, 2015.

Bieser, J., De Simone, F., Gencarelli, C., Geyer, B., Hedgecock, I., Matthias, V., Travnikov, O., and Weigelt, A.: A diagnostic evaluation of modeled mercury wet depositions in Europe using atmospheric speciated high-resolution observations, Environ. Sci. Pollut. R., 21, 9995-10012, 2014.

Carbone, F., Landis, M., Gencarelli, C., Naccarato, A., Sprovieri, F., Simone, F. D., Hedgecock, I., and Pirrone, N.: Sea Surface Temperature variation linked to elemental mercury concentrations measured on Mauna Loa, Geophys. Res. Lett., 43, 77517757, doi:10.1002/2016GL069252, 2016.

Chen, C. Y., Driscoll, C. T., Lambert, K. F., Mason, R. P., and Sunderland, E. M.: Connecting mercury science to policy: from sources to seafood, Rev. Environ. Health, 31, 17-20, 2016.

Corbitt, E. S., Jacob, D. J., Holmes, C. D., Streets, D. G., and Sunderland, E. M.: Global source-receptor relationships for mercury deposition under present-day and 2050 emissions scenarios, Environ. Sci. Technol., 45, 10477-10484, 2011.

D’Amore, F., Bencardino, M., Cinnirella, S., Sprovieri, F., and Pirrone, N.: Data quality through a web-based QA/QC system: implementation for atmospheric mercury data from the global mercury observation system, Environmental Science: Processes \& Impacts, 17, 1482-1491, 2015.

De Simone, F., Gencarelli, C., Hedgecock, I., and Pirrone, N.: Global atmospheric cycle of mercury: a model study on the impact of oxidation mechanisms, Environ. Sci. Pollut. R., 21, 41104123, 2014.

De Simone, F., Cinnirella, S., Gencarelli, C. N., Yang, X., Hedgecock, I. M., and Pirrone, N.: Model study of global mercury deposition from biomass burning, Environ. Sci. Technol., 49, 67126721, 2015.

De Simone, F., Gencarelli, C. N., Hedgecock, I. M., and Pirrone, N.: A Modeling Comparison of Mercury Deposition from Cur013/ rent Anthropogenic Mercury Emission Inventories, Environ. Sci. Technol., 50, 5154-5162, 2016.

Ebinghaus, R., Slemr, F., Brenninkmeijer, C. A. M., van Velthoven, P., Zahn, A., Hermann, M., O'Sullivan, D. A., and Oram, D. E.: Emissions of gaseous mercury from biomass burning in South America in 2005 observed during CARIBIC flights, Geophys. Res. Lett., 34, L08813, doi:10.1029/2006GL028866, 2007.

Emmons, L. K., Walters, S., Hess, P. G., Lamarque, J.-F., Pfister, G. G., Fillmore, D., Granier, C., Guenther, A., Kinnison, D., Laepple, T., Orlando, J., Tie, X., Tyndall, G., Wiedinmyer, C., Baughcum, S. L., and Kloster, S.: Description and evaluation of the Model for Ozone and Related chemical Tracers, version 4 (MOZART-4), Geosci. Model Dev., 3, 43-67, doi:10.5194/gmd3-43-2010, 2010.

Feng, X., Li, P., Qiu, G., Wang, S., Li, G., Shang, L., Meng, B., Jiang, H., Bai, W., Li, Z., and Fu, X.: Human Exposure To Methylmercury through Rice Intake in Mercury Mining Areas, 
Guizhou Province, China, Environ. Sci. Technol., 42, 326-332, 2008.

Finley, B., Swartzendruber, P., and Jaffe, D.: Particulate mercury emissions in regional wildfire plumes observed at the Mount Bachelor Observatory, Atmos. Environ., 43, 6074-6083, 2009.

Friedli, H., Arellano, A., Cinnirella, S., and Pirrone, N.: Initial Estimates of Mercury Emissions to the Atmosphere from Global Biomass Burning, Environ. Sci. Technol., 43, 3507-3513, 2009.

GFAS: Global Fire Assimilation System v1.2 documentation, available at: http://www.gmes-atmosphere.eu/about/project_ structure/input_data/d_fire/gfas_versions (last access: 1 June 2016), 2015.

Giglio, L., Randerson, J. T., and Werf, G. R.: Analysis of daily, monthly, and annual burned area using the fourth-generation global fire emissions database (GFED4), J. Geophys. Res.Biogeo., 118, 317-328, 2013.

Gustin, M. and Jaffe, D.: Reducing the uncertainty in measurement and understanding of mercury in the atmosphere, Environ. Sci. Technol., 44, 2222-2227, 2010.

Gustin, M. S., Amos, H. M., Huang, J., Miller, M. B., and Heidecorn, K.: Measuring and modeling mercury in the atmosphere: a critical review, Atmos. Chem. Phys., 15, 5697-5713, doi:10.5194/acp-15-5697-2015, 2015.

Holmes, C. D., Jacob, D. J., Corbitt, E. S., Mao, J., Yang, X., Talbot, R., and Slemr, F.: Global atmospheric model for mercury including oxidation by bromine atoms, Atmos. Chem. Phys., 10, 12037-12057, doi:10.5194/acp-10-12037-2010, 2010.

Hynes, A. J., Donohoue, D. L., Goodsite, M. E., and Hedgecock, I. M.: Our current understanding of major chemical and physical processes affecting mercury dynamics in the atmosphere and at the air-water/terrestrial interfaces, in: Mercury Fate and Transport in the Global Atmosphere: Emissions, Measurements and Models, edited by: Pirrone, N. and Mason, R. P., Chap. 14, 427457, Springer, 2009.

Janhäll, S., Andreae, M. O., and Pöschl, U.: Biomass burning aerosol emissions from vegetation fires: particle number and mass emission factors and size distributions, Atmos. Chem. Phys., 10, 1427-1439, doi:10.5194/acp-10-1427-2010, 2010.

Jung, G., Hedgecock, I. M., and Pirrone, N.: ECHMERIT V1.0 - a new global fully coupled mercury-chemistry and transport model, Geosci. Model Dev., 2, 175-195, doi:10.5194/gmd-2175-2009, 2009.

Kaiser, J. W., Heil, A., Andreae, M. O., Benedetti, A., Chubarova, N., Jones, L., Morcrette, J.-J., Razinger, M., Schultz, M. G., Suttie, M., and van der Werf, G. R.: Biomass burning emissions estimated with a global fire assimilation system based on observed fire radiative power, Biogeosciences, 9, 527-554, doi:10.5194/bg-9-527-2012, 2012.

Kaiser, J. W., Andela, N., Benedetti, A., He, J., Heil, A., Inness, A., Paugam, R., Remy, S., Trigo, I., van der Werf, G. R., and Wooster, M. J.: GFAS fire emissions and smoke in the Copernicus Atmosphere Monitoring Service, Geophys. Res. Abstr., EGU2015-15432, EGU General Assembly 2015, Vienna, Austria, 2015.

Kwon, S. Y. and Selin, N. E.: Uncertainties in Atmospheric Mercury Modeling for Policy Evaluation, Current Pollution Reports, 2, 103-114, 2016

Meng, B., Feng, X., Qiu, G., Anderson, C. W., Wang, J., and Zhao, L.: Localization and speciation of mercury in brown rice with implications for Pan-Asian public health, Environ. Sci. Technol., 48, 7974-7981, 2014.

Mu, M., Randerson, J. T., van der Werf, G. R., Giglio, L., Kasibhatla, P., Morton, D., Collatz, G. J., DeFries, R. S., Hyer, E. J., Prins, E. M., Griffith, D. W. T., Wunch, D., Toon, G. C., Sherlock, V., and Wennberg, P. O.: Daily and 3-hourly variability in global fire emissions and consequences for atmospheric model predictions of carbon monoxide, J. Geophys. Res.-Atmos., 116, D24303, doi:10.1029/2011JD016245, 2011.

Muntean, M., Janssens-Maenhout, G., Song, S., Selin, N. E., Olivier, J. G., Guizzardi, D., Maas, R., and Dentener, F.: Trend analysis from 1970 to 2008 and model evaluation of EDGARv4 global gridded anthropogenic mercury emissions, Sci. Total Environ., 494-495, 337-350, 2014.

Obrist, D., Moosmüller, H., Schürmann, R., Chen, L.-W. A., and Kreidenweis, S. M.: Particulate-phase and gaseous elemental mercury emissions during biomass combustion: controlling factors and correlation with particulate matter emissions, Environ. Sci. Technol., 42, 721-727, 2007.

Pacyna, J. M., Travnikov, O., De Simone, F., Hedgecock, I. M., Sundseth, K., Pacyna, E. G., Steenhuisen, F., Pirrone, N., Munthe, J., and Kindbom, K.: Current and future levels of mercury atmospheric pollution on a global scale, Atmos. Chem. Phys., 16, 12495-12511, doi:10.5194/acp-16-12495-2016, 2016.

Randerson, J., Chen, Y., Werf, G., Rogers, B., and Morton, D.: Global burned area and biomass burning emissions from small fires, J. Geophys. Res.-Biogeo., 117, G04012, doi:10.1029/2012JG002128, 2012.

Roeckner, E., Bäuml, G., Bonaventura, L., Brokopf, R., Esch, M., Giorgetta, M., Hagemann, S., Kirchner, I., Kornblueh, L., Manzini, E., Rhodin, A., Schlese, U., Schulzweida, U., and Tompkins, A.: The atmospheric general circulation model ECHAM5. PART I: Model description, MPIReport No. 349, available at: https://www.mpimet.mpg.de/ fileadmin/publikationen/Reports/max_scirep_349.pdf (last access: 5 May 2016), 2003.

Santer, B. D., Taylor, K. E., Wigley, T. M., Penner, J. E., Jones, P. D., and Cubasch, U.: Towards the detection and attribution of an anthropogenic effect on climate, Clim. Dynam., 12, 77-100, 1995.

Santer, B. D., Taylor, K. E., Wigley, T. M. L., Johns, T. C., Jones, P. D., Karoly, D. J., Mitchell, J. F. B., Oort, A. H., Penner, J. E., Ramaswamy, V., Schwarzkopf, M. D., Stouffer, R. J., and Tett, S.: A search for human influences on the thermal structure of the atmosphere, Nature, 382, 39-46, 1996.

Selin, N. E., Jacob, D. J., Yantosca, R. M., Strode, S., Jaeglé, L., and Sunderland, E. M.: Global 3-D land-ocean-atmosphere model for mercury: Present-day versus preindustrial cycles and anthropogenic enrichment factors for deposition, Global Biogeochem. Cy., 22, GB2011, doi:10.1029/2007GB003040, 2008.

Slemr, F., Brenninkmeijer, C. A., Rauthe-Schöch, A., Weigelt, A., Ebinghaus, R., Brunke, E.-G., Martin, L., Spain, T. G., and O'Doherty, S.: El Niño-Southern Oscillation influence on tropospheric mercury concentrations, Geophys. Res. Lett., 43, 17661771, 2016.

Solazzo, E. and Galmarini, S.: A science-based use of ensembles of opportunities for assessment and scenario studies, Atmos. Chem. Phys., 15, 2535-2544, doi:10.5194/acp-15-2535-2015, 2015. 
Sprovieri, F., Pirrone, N., Bencardino, M., D’Amore, F., Angot, H., Barbante, C., Brunke, E.-G., Arcega-Cabrera, F., Cairns, W., Comero, S., Diéguez, M. D. C., Dommergue, A., Ebinghaus, R., Feng, X. B., Fu, X., Garcia, P. E., Gawlik, B. M., Hageström, U., Hansson, K., Horvat, M., Kotnik, J., Labuschagne, C., Magand, O., Martin, L., Mashyanov, N., Mkololo, T., Munthe, J., Obolkin, V., Islas, M. R., Sena, F., Somerset, V., Spandow, P., Vardè, M., Walters, C., Wängberg, I., Weigelt, A., Yang, X., and Zhang, H.: Five-year records of Total Mercury Deposition flux at GMOS sites in the Northern and Southern Hemispheres, Atmos. Chem. Phys. Discuss., doi:10.5194/acp-2016-517, in review, 2016a.

Sprovieri, F., Pirrone, N., Bencardino, M., D’Amore, F., Carbone, F., Cinnirella, S., Mannarino, V., Landis, M., Ebinghaus, R., Weigelt, A., Brunke, E.-G., Labuschagne, C., Martin, L., Munthe, J., Wängberg, I., Artaxo, P., Morais, F., Barbosa, H. D. M. J., Brito, J., Cairns, W., Barbante, C., Diéguez, M. D. C., Garcia, P. E., Dommergue, A., Angot, H., Magand, O., Skov, H., Horvat, M., Kotnik, J., Read, K. A., Neves, L. M., Gawlik, B. M., Sena, F., Mashyanov, N., Obolkin, V., Wip, D., Feng, X. B., Zhang, H., Fu, X., Ramachandran, R., Cossa, D., Knoery, J., Marusczak, N., Nerentorp, M., and Norstrom, C.: Atmospheric mercury concentrations observed at ground-based monitoring sites globally distributed in the framework of the GMOS network, Atmos. Chem. Phys., 16, 11915-11935, doi:10.5194/acp16-11915-2016, 2016b.

Steffen, A., Bottenheim, J., Cole, A., Ebinghaus, R., Lawson, G., and Leaitch, W. R.: Atmospheric mercury speciation and mercury in snow over time at Alert, Canada, Atmos. Chem. Phys., 14, 2219-2231, doi:10.5194/acp-14-2219-2014, 2014.

Subir, M., Ariya, P. A., and Dastoor, A. P.: A review of uncertainties in atmospheric modeling of mercury chemistry I. Uncertainties in existing kinetic parameters - Fundamental limitations and the importance of heterogeneous chemistry, Atmos. Environ., 45, 5664-5676, 2011.

Subir, M., Ariya, P. A., and Dastoor, A. P.: A review of the sources of uncertainties in atmospheric mercury modeling II. Mercury surface and heterogeneous chemistry - A missing link, Atmos. Environ., 46, 1-10, 2012.

Travnikov, O., Angot, H., Artaxo, P., Bencardino, M., Bieser, J., D’Amore, F., Dastoor, A., De Simone, F., Diéguez, M. D. C., Dommergue, A., Ebinghaus, R., Feng, X. B., Gencarelli, C. N., Hedgecock, I. M., Magand, O., Martin, L., Matthias, V., Mashyanov, N., Pirrone, N., Ramachandran, R., Read, K. A., Ryjkov, A., Selin, N. E., Sena, F., Song, S., Sprovieri, F., Wip, D., Wängberg, I., and Yang, X.: Multi-model study of mercury dispersion in the atmosphere: Atmospheric processes and model evaluation, Atmos. Chem. Phys. Discuss., doi:10.5194/acp-2016-924, in review, 2016. van der Werf, G. R., Randerson, J. T., Giglio, L., Collatz, G. J., Mu, M., Kasibhatla, P. S., Morton, D. C., DeFries, R. S., Jin, Y., and van Leeuwen, T. T.: Global fire emissions and the contribution of deforestation, savanna, forest, agricultural, and peat fires (19972009), Atmos. Chem. Phys., 10, 11707-11735, doi:10.5194/acp10-11707-2010, 2010.

Veira, A., Kloster, S., Wilkenskjeld, S., and Remy, S.: Fire emission heights in the climate system - Part 1: Global plume height patterns simulated by ECHAM6-HAM2, Atmos. Chem. Phys., 15, 7155-7171, doi:10.5194/acp-15-7155-2015, 2015.

Wang, X., Zhang, H., Lin, C.-J., Fu, X., Zhang, Y., and Feng, X.: Transboundary transport and deposition of $\mathrm{Hg}$ emission from springtime biomass burning in the Indo-China Peninsula, J. Geophys. Res.-Atmos., 120, 9758-9771, 2015.

Wang, Y., Huang, J., Zananski, T. J., Hopke, P. K., and Holsen, T. M.: Impacts of the Canadian forest fires on atmospheric mercury and carbonaceous particles in northern New York, Environ. Sci. Technol., 44, 8435-8440, 2010.

Webster, J. P., Kane, T. J., Obrist, D., Ryan, J. N., and Aiken, G. R.: Estimating mercury emissions resulting from wildfire in forests of the Western United States, Sci. Total Environ., 568, 578-586, doi:10.1016/j.scitotenv.2016.01.166, 2016.

Wiedinmyer, C., Akagi, S. K., Yokelson, R. J., Emmons, L. K., AlSaadi, J. A., Orlando, J. J., and Soja, A. J.: The Fire INventory from NCAR (FINN): a high resolution global model to estimate the emissions from open burning, Geosci. Model Dev., 4, 625641, doi:10.5194/gmd-4-625-2011, 2011.

Witt, E. L., Kolka, R. K., Nater, E. A., and Wickman, T. R.: Forest fire effects on mercury deposition in the boreal forest, Environ. Sci. Technol., 43, 1776-1782, 2009.

Zhang, H., Feng, X., Larssen, T., Shang, L., and Li, P.: Bioaccumulation of methylmercury versus inorganic mercury in rice (Oryza sativa L.) grain, Environ. Sci. Technol., 44, 4499-4504, 2010.

Zhang, K., O’Donnell, D., Kazil, J., Stier, P., Kinne, S., Lohmann, U., Ferrachat, S., Croft, B., Quaas, J., Wan, H., Rast, S., and Feichter, J.: The global aerosol-climate model ECHAM-HAM, version 2: sensitivity to improvements in process representations, Atmos. Chem. Phys., 12, 8911-8949, doi:10.5194/acp-12-89112012, 2012.

Zhang, Y., Obrist, D., Zielinska, B., and Gertler, A.: Particulate emissions from different types of biomass burning, Atmos. Environ., 72, 27-35, 2013. 